\title{
A general review of power quality standards and terminologies
}

\author{
V.A Deshmukh \\ M.Tech scholar \\ Department of electrical engineering \\ Christian college of engineering and technology Bhilai,Chhattisgarh,India \\ email-vdeshmukh203@gmail.com \\ ORCID ID-https://orcid.org/0000-0001-6745-7062 \\ B.Sridhar \\ Assistant professor \\ Department of electrical engineering Christian college of engineering and technology \\ Bhilai,ChhattisgarhIndia \\ email-burlasridhar@gmail.com \\ ORCID ID-https://orcid.org/0000-0002-0234-5112
}

\begin{abstract}
In the next few years, more than $80 \%$ of $\mathrm{AC}$ power is to be processed through power converters owing to their benefits of energy conservation, flexibility, network interconnection, and weight and volume reduction in a number of equipment such as lighting arrestors, HVAC computers, fans, and so on.This paper gives an introduction on power quality (PQ), causes and effects of power quality problems. It also deals with power quality definitions, terminologies, standards, bench-marks, monitoring requirements, financial loss, and analytical quantification. It also discusses various types of nonlinear loads, which cause these power quality problems, they are illustrated, classified, modeled, quantified, and analyzed forassociated power quality issues.
\end{abstract}

Keywords: AC Power, convertors, power quality definitions terminologies standards benchmarks, power quality problems,nonlinear loads. 


\section{Introduction}

Power quality has become an important subject and area of research thanks to its increasing awareness and impacts on the consumers, manufacturers, and utilities. Many technical institutions, industries, and R\&D organizations are offering regular and short-term courses on power quality. There are a spread of power quality problems within the present-day fast-changing electrical systems. The most causes of those problems are often classified into natural and man-made causes. Natural causes end in problems that are generally transient in nature, like voltage distortion, swell, and impulsive and oscillatory transients. The facility quality problems affect all concerned utilities, customers, and makers directly or indirectly. These problems affect the monitoring systems in much critical, emergency, vital, and dear equipment. Harmonic currents increase losses during a number of electrical equipment and distribution systems

\subsection{An introduction on power quality (PQ)}

\subsubsection{Introduction}

Electric power quality (PQ) is generally used to assess and to maintain the good quality of power at the level of generation, transmission, distribution, and utilization of AC electrical power.

Power quality is quantified in terms of voltage, current, or frequency deviation of the supply system. These power quality problems cause failure of capacitor banks, increased losses in the distribution system and electric machines, noise, vibrations, over-voltages and excessive current. The problems have become much more serious with the use of solid-state controllers.

Power quality has become an important area of study in electrical engineering. It has created a great challenge to both electric utilities and electrical distribution entities.A number of techniques have evolved for the mitigation of these problems either in existing systems or in equipment to be developed in the near future. It has resulted in a new direction of research and development (R\&D) activities for the design and developmentengineers.

Power quality improvement techniques used in newly designed and developed systems are based on the modification of the input stage of these systems. In existing nonlinear loads, a series of power filters are used externally to mitigate power quality problems. This paper is aimed at providing an awareness of the power quality problems, their causes and adverse effects. 


\subsubsection{Awarenss among customers}

The power quality problems have been present since the inception of electric power. However, recently the awareness of the customers toward the power quality problems has increased tremendously because of the following reasons:

-The customer's equipment have become more sensitive to power quality problems

-Solid-state controllers have increased harmonic levels, distor- tion, notches, and other power quality problems. Typical examples are ASDs and electronic ballasts, which have substantial energy savings.

- The awareness of power quality problems has increased in the customers.

- The disturbances to other important appliances such as telecom communication network, TVs,

- The deregulation of the power systems has increased the importance of power quality.

- Distributed generation using renewable energy has increased power quality problems as it needs.

- Power network contamination and power quality concerns has become an environmental concern with other implications in addition to financial concerns, similar to other types of emissions such as air pollution.

- As the law and discipline of the country, several rules and protocols are developed and implemented on consumers, producers, and utilities

\subsubsection{Power Quality:Classification}

In today's fast-changing electrical grids, there are a host of power quality issues. This may be categorised based on transient and steady- state occurrences and quantities like current, voltage, and frequency, or load and supply networks.

- Many transient events (e.g., impulsive or oscillatory in nature) are included in the transient forms of power quality issues, such as sag (dip), swell, short-duration voltage changes, power frequency variations, and voltage fluctuations.

-Long-duration voltage anomalies, waveform distortions, unbalanced voltages, notches, DC offset, flicker, low control factor, unbalanced load currents, load harmonic currents, and excessive neutral current are all examples of steady-state power qualityissues.

-Voltage distortions, flicker, notches, noise, sag, swell, unbalance, undervoltage, and overvoltage are all examples of voltage distortions.

- Reactive power portion of current, harmonic currents, unbalanced currents, and excessive neutral current are all examples of current problems. 
- Load current with harmonics, reactive power portion of cur- rent, unbalanced currents, neutral current, DC offset, and other power quality issues are caused by the design of the load.

-Voltage and frequency-related issues such as notches, voltage imbalance, unbalance, sag, swell, flicker, and noise are all caused by supply system issues. These may also include a mix of voltage and current-based power quality issues in the device.

- Hertz variations above or below the target base value are fre- quency-related power quality issues. These have an effect on the efficiency of a variety of loads and other devices in the delivery system, such as transformers. 


\subsubsection{Problems with Power Quality: What Causes Them?}

In today's fast-changing electrical grids, there are a host of power quality issues. In terms of current, voltage, frequency, and soon, the key causes of these power quality issues can be categorised as normal and man-made. Faults, lightning, atmospheric hazards such as storms, system loss, and storms are the most common natural causes of low power efficiency. The man-made triggers, on the other hand, are often attributable to loads or machine operations. Nonlinear loads, such as saturating transformers and other electrical devices, as well as loads of solid-state controls, such as vapour lamp-based lighting systems, ASDs, UPSs, arc furnaces, computing power supplies, and televisions, are among the sources.

Switching of transformers, capacitors, feeders, and heavy loads are the sources of power quality issues related to system operations. Normal causes cause power quality issues like voltage sag (dip), voltage distortion, swell, and impulsive and oscillatory transients, which are all transient in nature. Man-made triggers, on the other hand, result in both intermittent and steady-state power efficiency issues. Any of the power quality issues and their causes are mentioned in Table 1.1.4(a). However, one of the more serious power quality issues is the pres- ence of harmonics, which can be caused by a variety of nonlinear loads, like transformers, electrical machines, and furnaces, as well as newer ones including power converters in vapour lamps, switched- mode power supplies (SMPS), ASDs using AC-DC converters, cyclo-converters, and AC voltage controllers.

Table 1.1.4(a) Power quality issues and causes.

\begin{tabular}{|c|c|c|c|c|}
\hline \multicolumn{5}{|c|}{ 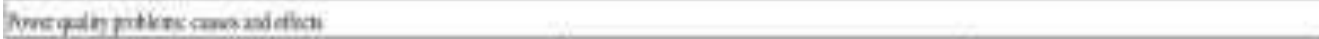 } \\
\hline pallon: & Casgicy & Ciseporiaice & Case & Mnos \\
\hline frovima & 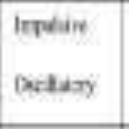 & 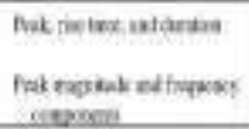 & 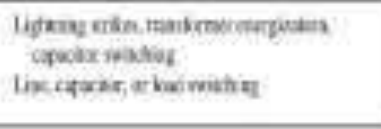 & 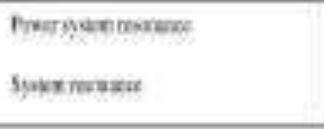 \\
\hline $\begin{array}{l}\text { Serd-defia } \\
\text { mbovenove }\end{array}$ & $\begin{array}{l}\text { Sas } \\
\text { Sondl } \\
\text { Iranatia }\end{array}$ & 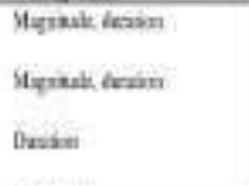 & 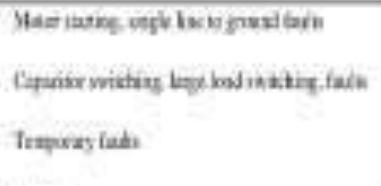 & 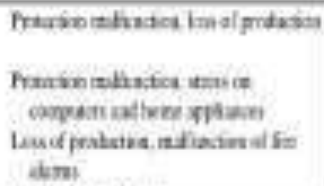 \\
\hline 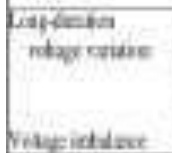 & 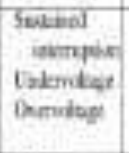 & 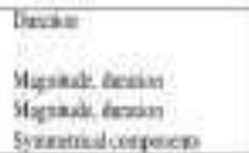 & 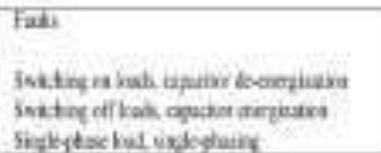 & 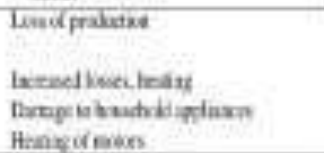 \\
\hline Wrodrnduagin & 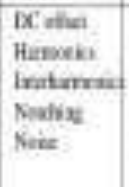 & 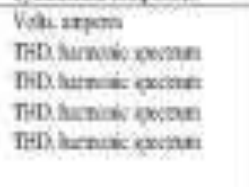 & 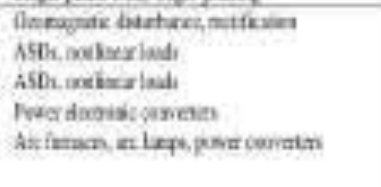 & 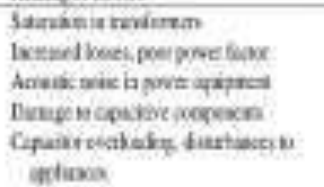 \\
\hline Velpipat & & 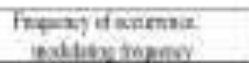 & Axintsica an & 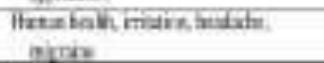 \\
\hline 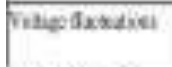 & & |kareialat & Looleager & 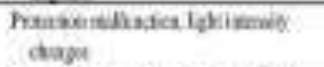 \\
\hline $\begin{array}{l}\text { Kanebragas: } \\
\text { natavas }\end{array}$ & & & 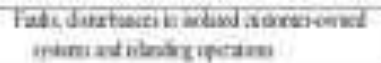 & 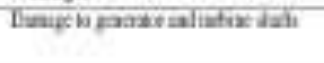 \\
\hline
\end{tabular}




\subsubsection{Users' Reactions to Issues with Power Quality.}

All of the affected utilities, consumers, and suppliers suffer direct or indirect financial losses as a result of process interruptions, equipment destruction, manufacturing losses, raw material waste, and the loss of critical records, among other things. There are many instances and implementations, such as automated production systems, such as semi- conductor processing, pharmaceutical manufacturing, and banking, where even a minor voltage dip/sag triggers process delay for several hours, raw material waste, and so on.

Any power quality issues wreak havoc on security schemes, causing safety equipment to malfunction. Many activities and procedures of factories and other establishments are disrupted by these. Many types of measurement instruments and metering of different quantities such as voltage, current, electricity, and energy are also affected. Further- more, these issues have an effect on the monitoring systems in a wide range of sensitive, essential, emergency, crucial, and expensive equipment.

Harmonic currents cause energy waste, inadequate use of utility properties such as transformers and feeders, overloading of power capacitors, noise and vibrations in electrical devices, and disruption and interruption to electronics appliances and communication net- works by increasing losses in a variety of electrical equipment and distribution systems. 


\subsection{Standards and Monitoring of Power Quality}

\subsubsection{Introduction}

There has been exponentially growing interest in power quality (PQ) in the past quarter century. Some of the main reasons for this have been enhanced sensitivity of equipment and increased cost of electricity globally.Power quality problems affect the customers in a number of ways such as economic penalty in terms of power loss, equipment failure, mal-operation, interruption in the process, and loss of pro- duction. Many industries are developing instruments, recorders, and analyzers to measure power quality.

This section deals with the state of the art on power quality standards and monitoring.

\subsubsection{Power Quality Standards and Monitoring: A modern take}

From the beginning of electric power, there have been challenges and concerns with power efficiency. The language of power efficiency, on the other hand, does not date back to the early days and has been known by a variety of other terms. Power efficiency has been a very familiar terminology and well understood over the last few decades. Similarly, as technology advances, many standards have been established, updated, recommended, and applied to ensure and measure the level of power efficiency.

List of some standards are written below- 
Table 1.2.2(a) Power Quality Standards

\begin{tabular}{|c|c|}
\hline Standards & Description \\
\hline IEEE Standard 519-1992 & $\begin{array}{l}\text { Recommended Practices and Requirements } \\
\text { for Harmonic Control in Electrical Power Systems }\end{array}$ \\
\hline IEEE Standard 1159-1995 & $\begin{array}{l}\text { ommended Practice for } \\
\text { Monitoring Electric Power Quality }\end{array}$ \\
\hline IEEE Standard 1100-1999 & $\begin{array}{l}\text { oommended Practice for Powering and } \\
\text { Grounding Sensitive Electronic Equipment }\end{array}$ \\
\hline IEEE Standard 1250-1995 & $\begin{array}{l}\text { Guide for Service to Equipment } \\
\text { Sensitive to Momentary Voltage Disturbances }\end{array}$ \\
\hline IEEE Standard 1366-2012 & Electric Power Distribution Reliability Indices \\
\hline IEC $61000-2-2$ & $\begin{array}{l}\text { mpatibility Levels for Low-Frequency } \\
\text { onducted Disturbances and Signaling in Public Supply } \\
\text { Systems }\end{array}$ \\
\hline IEC 61000-2-4 & $\begin{array}{l}\text { mpatibility Levels in Industrial Plants for } \\
\text { Low-Frequency Conducted Disturbances }\end{array}$ \\
\hline IEC 61000-3-2 & $\begin{array}{l}\text { its for Harmonic Current Emissions } \\
\text { (Equipment Input Current Up to a nd Including } 16 \mathrm{~A} \\
\text { Per Phase) }\end{array}$ \\
\hline IEC 61000-4-15 & Flicker Meter - Functional and Design Specifications \\
\hline EN 50160 & Voltage Characteristics of Public Distribution Systems \\
\hline IEEE 519-1992 & Permissible level of waveform distortion \\
\hline IEEE Std141-1993 & $\begin{array}{l}\text { ommended Practice for Electrical Power } \\
\text { Distribution for Industrial Plants. }\end{array}$ \\
\hline IEEE Std142-1991 & $\begin{array}{l}\text { fommended Practice for Grounding of } \\
\text { Industrial \& Commercial Power System }\end{array}$ \\
\hline IEEE Std241-1990 & $\begin{array}{l}\text { ommended Practice for Electric Power } \\
\text { Systems in Commercial Buildings. }\end{array}$ \\
\hline IEEE Std242-2001 & $\begin{array}{l}\text { lommended Practice for Protection and } \\
\text { Coordination of Industrial and Commercial Power } \\
\text { Systems }\end{array}$ \\
\hline IEEE Std446-1995 & $\begin{array}{l}\text { ommended Practice for Emergency and } \\
\text { Standby Power Systems for } \\
\text { Industrial and Commercial Applications }\end{array}$ \\
\hline IEEE Std493-1997 & $\begin{array}{l}\text { Commended Practice for the Design of } \\
\text { Reliable Industrial \& Commercial Power Systems }\end{array}$ \\
\hline IEEE Std 1100-1999 & $\begin{array}{l}\text { commended Practice for Powering and } \\
\text { Grounding Electronic Equipment }\end{array}$ \\
\hline IEEE Std 1250-1995 & $\begin{array}{l}\text { E Equipment Disturbances. Sensitive } \\
\text { to Guide for Service to Momentary Voltage }\end{array}$ \\
\hline IEEE Std 1346-1998 & $\begin{array}{l}\text { fommended Practice for Evaluating } \\
\text { Electric Power System Compatibility with Electronic } \\
\text { Process Equipment }\end{array}$ \\
\hline IEEE Std518-1982 & $\begin{array}{l}\text { E Guide for the Installation of Electrical } \\
\text { Equipment to Minimize Electrical Noise Inputs to } \\
\text { Controllers from External Sources }\end{array}$ \\
\hline IEEE C62.21-2003 & $\begin{array}{l}\text { E Guide for the Application of Surge } \\
\text { Voltage Protective Equipment on AC Rotating } \\
\text { Machinery } 1000 \text { Voltsand Greater }\end{array}$ \\
\hline IEEE C62.22.1-1996 (R2003) E & $\begin{array}{l}\text { Guide for the Connection of Surge } \\
\text { Arrestors to Protect Insulated, Shielded Electric } \\
\text { Power Cable Systems }\end{array}$ \\
\hline IEEE SidC62.22.1997 & $\begin{array}{l}\text { E Guide for the Application of } \\
\text { Metal Oxide Surge Arrestors for Alternating Current } \\
\text { Systems }\end{array}$ \\
\hline IEEE StdC62.41-1991 & $\begin{array}{l}\text { E Recommended Practice on } \\
\text { Surge Voltage in low Voltage AC Power Circuits. }\end{array}$ \\
\hline IEEE C62.41.1-2002 & $\begin{array}{l}\text { E Guide on the 'Surge Environment } \\
\mathrm{n} \text { Low Voltage (IOOOV and less) AC Power Circuits }\end{array}$ \\
\hline IEEE C62.41.2-2002 & $\begin{array}{l}\text { E Recommended Practice on } \\
\text { Characterization of Surges in Low Voltage (looov } \\
\text { and less) AC Power Circuits }\end{array}$ \\
\hline IEEE Std C62.42-1992 & $\begin{array}{l}\text { E Guide for the Application of } \\
\text { Gas-Tube and Air Gap Arrestor Low Voltage (Equal } \\
\text { to or Less than 1000Vrrns or } 1200 \mathrm{Vdc} \text { ) } \\
\text { Surge Protective Devices }\end{array}$ \\
\hline
\end{tabular}




\subsubsection{Terminologies for Power Quality}

Because power quality challenges, recognition, and mitigating strate- gies have been reported to a high degree of concern, different termi- nologies to measure power quality problems have been developed.

See the terminology and definitions mentioned below, which are specified in detail in IEEE Standards [24]:

- Flicker: Impression of unsteadiness of visual sensation induced by a light stimulus whose luminance or spectral distribution fluctuates with time.

- Fundamental (component): The component of order 1 (e.g., $50 \mathrm{~Hz}, 60 \mathrm{~Hz}$ ) of the Fourier series of a periodic quantity.

-Imbalance (voltage or current): The ratio of the negative- sequence component to the positive sequence component, usu- ally expressed as a percentage. Syn: unbalance (voltage or current).

-Impulsive transient: A sudden non-power frequency change in the steady-state condition of voltage or current that is unidirectional in polarity (primarily either positive or negative).

-Instantaneous: When used to quantify the duration of a short- duration root-mean-square (rms) variation as a modifier, it refers to a time range from 0.5 to 30 cycles of the power frequency.

- Interharmonic (component): A frequency component of a periodic quantity that is not an integer multiple of the frequency at which the supply system is operating (e.g., $50 \mathrm{~Hz}, 60 \mathrm{~Hz}$ ).

- Long-duration rms variation: A variation of the rms value of the voltage or current from the nominal value for a time greater than $1 \mathrm{~min}$. The term is usually further described using a modifier indicating the magnitude of a voltage variation (e.g., under- voltage, overvoltage, and voltage interruption).

- Momentary interruption: A type of short-duration rms voltagevariation where a complete loss of voltage $(<0.1 \mathrm{pu})$ on one or more phase conductors is for a time period between 0.5 cycle and $3 \mathrm{~s}$.

- Root-mean-square variation: A term often used to express a variation in the rms value of a voltage or current measurement from the nominal value. See sag, swell, momentary interruption, temporary interruption, sustained interruption, undervoltage, and overvoltage.

- Short-duration rms variation: A variation of the rms value of the voltage or current from the nominal value for a time greater than 0.5 cycle of the power frequency but less than or equal to 1 min. When the rms variation is voltage, it can be further described using a modifier indicating the magnitude of a

- voltage variation (e.g., sag, swell, and interruption) and pos- sibly a modifier indicating the duration of the variation (e.g., instantaneous, momentary, and temporary). 
- Sustained interruption: A type of long-duration rms voltage variation where the complete loss of voltage $(<0.1 \mathrm{pu})$ on one or more phase conductors is for a time greater than $1 \mathrm{~min}$.

- Temporary interruption: A type of short-duration rms varia- tion where the complete loss of voltage $(<0.1 \mathrm{pu})$ on one or more phase conductors is for a time period between $3 \mathrm{~s}$ and $1 \mathrm{~min}$.

- Voltage change: A variation of the rms or peak value of a voltage between two consecutive levels sustained for definite but unspecified durations.

- Voltage fluctuation: A series of voltage changes or a cyclic vari- ation of the voltageenvelope.

- Voltage interruption: The disappearance of the supply voltage on one or more phases. It is usually qualified by an additional term indicating the duration of the interruption (e.g., momen- tary, temporary, and sustained).

- Waveform distortion: A steady-state deviation from an ideal sine wave of power frequency principally characterized by the spectral content of the deviation.

- Accuracy: The quality of freedom from mistake or error, that is, of conformity to truth or to a rule (as in instrumentation and measurement). The accuracy of an indicated or recorded value is expressed by the ratio of the error of the indicated value to the true value. It is usually expressed in percent. See accuracy rating of an instrument (as indicated or recorded value).

- Calibration: The adjustment of a device to have the designed operating characteristics, and the subsequent marking of the positions of the adjusting means, or the making of adjustments necessary to bring operating characteristics into substantial agreement with standardized scales or marking.

- Comparisonof the indication of the instrument under test, or registration of the meter under test, with an appropriate standard (as in metering).

- Common-mode voltage: The voltage that, at a given location, appears equally and in phase from each signal conductor to ground.

- Coupling: The association of two or more circuits or systems in such a way that power or signal information may be transferred from one system or circuit to another.

- Current transformer (CT): An instrument transformer designed for use in the measurement or control of current (as in metering).

- Dropout: A loss of equipment operation (discrete data signals) due to noise, voltage sags, or interruption.

- Electromagnetic compatibility (EMC): A measure of equip- ment tolerance to external electromagnetic fields. The ability of a device, equipment, or system to function satisfactorily in its electromagnetic environment without introducing intolerable electromagnetic disturbances to anything in that environment. 
1

- Electromagnetic disturbance: An electromagnetic phenomenon that may be superimposed on a wanted signal. Any electro- magnetic phenomenon that may degrade the performance of a device, a piece of equipment, or a system.

- Equipment grounding conductor: The conductor used to con- nect the noncurrent-carrying parts of conduits, raceways, and equipment enclosures to the grounding electrode at the service equipment (main panel) or secondary of a separately derived system.

- Failure mode: The manner in which failure occurs; generally categorized as electrical, mechanical, thermal, and contamina-tion.

- Frequency deviation: An increase or decrease in the power fre- quency from the nominal value. The duration of a frequency deviation can be from several cycles to several hours.

- Ground: A conducting connection, whether intentional or acci- dental, by which an electric circuit or equipment is connected to the earth, or to some conducting body of relatively large extent that serves in place of the earth. Grounds are used for establishing and maintaining the potential of the earth (or of the conducting body) or approximately that potential, on conductors connected to it, and for conducting ground currents to and from earth (or the conducting body).

- Ground loop: A potentially detrimental loop formed when two or more points in an electrical system that are nominally at ground potential are connected by a conducting path such that either or both points are not at the same ground potential.

- Harmonic: A sinusoidal component of a periodic wave or quantity having a frequency that is an integral multiple of the fundamental frequency. For example, a component having a frequency twice the fundamental frequency is called a second harmonic.

-Harmonic components: The components of the harmonic con- tent expressed in terms of the order and rms values of the Fourier series terms describing the periodic function.

- Harmonic content: The function obtained by subtracting the DC and fundamental components from a non-sinusoidal periodic function. The deviation from the sinusoidal form, expressed in terms of the order and magnitude of the Fourier series terms describing the wave. Distortion of a sinusoidal waveform characterized by indication of the magnitude and order of the Fourier series terms describing the wave.

-Immunity (to a disturbance): The ability of a device, equipment, or system to perform without degradation in the presence of an electromagnetic disturbance.

-Impulse: A pulse that begins and ends within a time so short that it may be regarded mathematically as infinitesimal, although the area remains finite. An impulse is a surge of unidirectional polarity 
-Isolated equipment ground: An isolated equipment grounding conductor run in the same conduit or raceway as the supply conductors. This conductor may be insulated from the metallic raceway and all ground points throughout its length. It origi- nates at an isolated ground-type receptacle or equipment input terminal block and terminates at the point where neutral and ground are bonded at the power source.

- Isolation: Separation of one section of a system from undesired influences of other sections.

- Maximum demand: The largest of a particular type of demand occurring within a specified period.

- Momentary: When used as a modifier to quantify the duration of a short-duration variation, it refers to a time range from 30 cycles to $3 \mathrm{~s}$.

- Momentary interruption: A type of short-duration variation. The complete loss of voltage $(<0.1 \mathrm{pu})$ on one or more phase conductors for a time period between 0.5 cycle and $3 \mathrm{~s}$.

- Noise: Electrical noise is unwanted electrical signals that pro- duce undesirable effects in the circuits of the control systems in which they occur.

- Nominal voltage: A nominal value assigned to a circuit or system for the purpose of conveniently designating its voltage class (as $208 \mathrm{~V} / 120 \mathrm{~V}, 480 \mathrm{~V} / 277 \mathrm{~V}, 600 \mathrm{~V}$ ).

- Nonlinear load: A load that draws a nonsinusoidal current wave when supplied by a sinusoidal voltage source.

- Normal-mode voltage: The voltage that appears differentially between two signal wires and that acts on the circuit in the same manner as the desired signal.

- Notch: A switching (or other) disturbance of the normal power voltage waveform, lasting less than a half cycle, which is initially of opposite polarity to the waveform and is thus subtracted from the normal waveform in terms of the peak value of the disturbance voltage. This includes complete loss of voltage for up to a half cycle.

- Oscillatory transient: A sudden, non-power frequency change in the steady-state condition of voltage or current that includes either positive or negative polarity value.

- Overvoltage: When used to describe a specific type of long- duration variation, it refers to a measured voltage having a value greater than the nominal voltage for a time greater than $1 \mathrm{~min}$. The typical values are 1.1-1.2 pu.

-Phase shift: The displacement in time of one waveform relative to another of the same frequency and harmonic content.

- Point of common coupling (PCC): The point at which the elec- tric utility and the customer interface occurs. Typically, this point is the customer side of the utility revenue meter.

- Potential transformer (PT): An instrument transformer that isintended to have its primary winding connected in shunt with a power supply circuit, the voltage of which is to be measured or controlled. 
- Power disturbance: Any deviation from the nominal value (or from some selected thresholds based on load tolerance) of the input AC power characteristics.

- Power quality: The concept of powering and grounding elec- tronic equipment in a manner that is suitable to the operation of that equipment and compatible with the premise wiring system and other connected equipment.

- Pulse: A wave that departs from an initial level for a limited duration of time and ultimately returns to the original level.

- Sag: A decrease in rms voltage or current for durations of 0.5 cycle to $1 \mathrm{~min}$. The typical values are 0.1-0.9 pu.

- Shield: A metallic sheath, usually copper or aluminum, applied over the insulation of a conductor(s) for the purpose of pro- viding means for reducing electrostatic coupling between the conductor(s) so shielded and others that may be susceptible to or that may be generating unwanted (noise) electrostatic fields.

- Shielding: The process of applying a conductive barrier between a potentially disturbing noise source and electronic circuitry. Shields are used to protect cables (data and power) and elec- tronic circuits. Shielding may be accomplished by the use of metal barriers, enclosures, or wrappings around source circuits and receiving circuits.

- Sustained: When used to quantify the duration of a voltage interruption, it refers to the time frame associated with a long- duration variation (i.e., greater than $1 \mathrm{~min}$ ).

- Sustained interruption: A type of long-duration variation. Thecomplete loss of voltage $(<0.1 \mathrm{pu})$ on one or more phase con- ductors for a time greater than $1 \mathrm{~min}$.

- Swell: An increase in rms voltage or current for durations from

0.5 cycle to $1 \mathrm{~min}$. The typical values are 1.1-1.8 pu.

- Temporary interruption: A type of short-duration variation. The complete loss of voltage $\quad<0.1$ $\mathrm{pu}$ ) on one or more phase conductors for a time period between $3 \mathrm{~s}$ and $1 \mathrm{~min}$.

- Total demand distortion (TDD): The total rms harmonic cur- rent distortion, in percent of the maximum demand load current (15 or 30 min demand).

- Total harmonic distortion (THD) (HF: harmonic factor): The ratio of the rms value of the harmonic content to the rms value of the fundamental quantity, expressed as a percent of the fundamental.

- Transient: Pertaining to or designating a phenomenon or a quantity that varies between two consecutive steady states during a time interval that is short compared to the timescale of interest. A transient can be a unidirectional impulse of either polarity or a damped oscillatory wave with the first peak occur- ring in either polarity. 
- Undervoltage: When used to describe a specific type of long- duration variation, it refers to a measured voltage having a value less than the nominal voltage for a time greater than $1 \mathrm{~min}$. The typical values are $0.8-0.9 \mathrm{pu}$.

-Voltage distortion: Any deviation from the nominal sine wave form of the AC line voltage.

-Voltage imbalance (unbalance): The ratio of the negative- or zero-sequence component to the positive- sequence component, usually expressed as a percentage in polyphase systems.

-Voltage regulation: The degree of control or stability of the rms voltage at the load. Often specified in relation to other parameters, such as input voltage changes, load changes, or temperature changes. 


\subsubsection{Definitions for Power Quality}

Power quality is defined in many sources, which give different meaning to different people. It is used synonymously with supply reliability, service quality, voltage quality, quality of supply, and quality of consumption. In general, power quality is related to disturbances in voltage, current, frequency, and power factor. Any deviation in the voltage or current from the ideal value is a power quality disturbance. The definition of power quality has not been universally agreed upon. International Electrotechnical Commission (IEC) provides a description of power quality in IEC 61000-4-30 which states power quality as "Power quality is the principle of powering and grounding sensitive equipment in a manner that is appropriate for the operation of that equipment," and according to the Institute of Electrical and Electronics Engineers(IEEE)dictionary power quality means "Characteristics of the energy at a specified point on an electrical grid, measured against a set of reference technical parameters"

\subsubsection{Standards for Power Quality}

When power quality issues reach a point where they begin to affect not just those that are causing them, but also other customers, it becomes a cause for concern. A number of organisations, including the International Electrotechnical Commission (IEC), the American National Standards Institute (ANSI), British Standards (BS), European Norms (EN), Computer Business Equipment Manufacturers Association (CBEMA), and the Information Technology Industry Council (ITIC), have established standards to specify the permissible limits of various performance indices to mitigate power pollution.

Some of those limits are defined below.

Table 1.2.5(a). IEEE Standard 519-1992: current distortion limits for general distribution systems $(120-69000 \mathrm{~V})$

\begin{tabular}{|l|l|l|l|l|l|l|}
\hline \multicolumn{7}{|l|}{ Maximum harmonic current distortion (in percet of $I_{l}$ ) } \\
\hline$I_{\mathrm{sc}} / I_{l}$ & $\mathrm{~h}<11$ & $116 h<17$ & $176 h<23$ & $236 h<35$ & $356 h$ & $\mathrm{TDD}(\%)$ \\
\hline$<20$ & 4.0 & 2.0 & 1.5 & 0.6 & 0.3 & 5.0 \\
\hline 20 to $<50$ & 7.0 & 3.5 & 2.5 & 1.0 & 0.5 & 8.0 \\
\hline 50 to $<100$ & 10.0 & 4.5 & 4.0 & 1.5 & 0.7 & 12.0 \\
\hline 100 to $<1000$ & 12.0 & 5.5 & 5.0 & 2.0 & 1.0 & 15.0 \\
\hline$>1000$ & 15.0 & 7.0 & 6.0 & 2.5 & 1.4 & 20.0 \\
\hline
\end{tabular}

$I_{\mathrm{sc}}=$ maximum short-circuit current at $\mathrm{PCC}$ and;

$I l=$ maximum demand load current (fundamental frequency component) at PCC.

$\mathrm{h}=$ harmonic order with respect to fundamental frequency.

Table 1.2.5(b) IEEE Standard 519-1992: current distortion limits forgeneral distribution systems $(>161 \mathrm{kV})$, dispersed generation and cogeneration

\begin{tabular}{|l|l|l|l|l|l|l|l|}
\hline \multicolumn{7}{|c|}{ Maximum harmonic current distortion (in percent of $I_{l}$ ) } \\
\hline$I_{\text {sc }} / I_{l}$ & h $<11$ & $116 h<17$ & $176 h<23$ & $236 h<35$ & $356 h$ & $\mathrm{TDD}(\%)$ \\
\hline$<50$ & 2.0 & 1.0 & 0.75 & 0.3 & 0.15 & 2.5 \\
\hline$>50$ & 3.0 & 1.5 & 1.15 & 0.45 & 0.22 & 3.75 \\
\hline
\end{tabular}


Table 1.2.5(b) IEEE Standard 519-1992: voltage distortion limits

\begin{tabular}{|l|l|l|}
\hline $\begin{array}{l}\text { voltage } \\
\text { at PCC }\end{array}$ & $\begin{array}{l}\text { ividual voltage } \\
\text { distortion (\%) }\end{array}$ & $\begin{array}{l}\text { laltage } \\
\text { distortion(\%) }\end{array}$ \\
\hline $69 \mathrm{kV}$ and below & 3.0 & 5.0 \\
\hline 69.001 to $161 \mathrm{kV}$ & 1.5 & 2.5 \\
\hline 161.001 and above & 1.0 & 1.5 \\
\hline
\end{tabular}

Table 1.2.5(c) IEC 61000-2-4: voltage distortion limits in industrialplant (class 2)

\begin{tabular}{|c|c|c|c|c|c|}
\hline \multicolumn{2}{|c|}{ Odd harmonics } & \multicolumn{2}{|c|}{ Even harmonics } & \multicolumn{2}{|c|}{ Triplen harmonics } \\
\hline $\mathrm{h}$ & $V_{h}(\mathrm{pu})$ & $\mathrm{h}$ & $V_{h}(\mathrm{pu})$ & $\mathrm{h}$ & $V_{h}(\mathrm{pu})$ \\
\hline 05 & 6.0 & 02 & 2 & 03 & 5 \\
\hline 07 & 5.0 & 04 & 1 & 09 & 1.5 \\
\hline$\overline{11}$ & 3.5 & 06 & 0.5 & 15 & 0.3 \\
\hline 13 & 3.0 & 08 & 0.5 & $>21$ & 0.2 \\
\hline 17 & 2.0 & 10 & 0.5 & & \\
\hline 19 & 1.5 & $>12$ & 0.2 & & \\
\hline 23 & 1.5 & & & & \\
\hline 25 & 1.5 & & & & \\
\hline$>2$ & $2+12.5 \mathrm{lh}$ & & & & \\
\hline
\end{tabular}

Table 1.2.5(d) . IEC 61000-2-4: voltage distortion limits in industrial plants (class 3)

\begin{tabular}{|c|c|c|c|c|c|}
\hline \multicolumn{2}{|c|}{ Odd harmonics } & \multicolumn{2}{|c|}{ Even harmonics } & \multicolumn{2}{|c|}{ Triplen harmonics } \\
\hline $\mathrm{h}$ & $V_{h}(\mathrm{pu})$ & $h$ & $V_{h}(\mathrm{pu})$ & $h$ & $V_{h}(\mathrm{pu})$ \\
\hline 05 & 6.0 & 02 & 2 & 03 & 6.0 \\
\hline 07 & 5.0 & 04 & 1 & 09 & 2.5 \\
\hline 11 & 3.5 & $>06$ & 0.5 & 15 & 2.0 \\
\hline 13 & 3.0 & & & 21 & 1.75 \\
\hline 17 & 2.0 & & & \multirow[t]{5}{*}{$>27$} & \multirow[t]{5}{*}{1} \\
\hline 19 & 1.5 & & & & \\
\hline 23 & 1.0 & & & & \\
\hline 25 & 1.5 & & & & \\
\hline$>2$ & $11 / h)$ & & & & \\
\hline
\end{tabular}




\subsubsection{Monitoring of Power Quality}

PQ incidents are haphazard in nature and occur at random. As a result, tracking the PQ phenomenon becomes almost inevitable for vital and expensive equipment where PQ issues are likely to result in a significant loss of revenue. If these recording/measuring instru- ments are correctly chosen to record PQ events, the monitoring device used for evaluating PQ events which provide enough data to decide on curing and minimising power quality problems. There are several guidelines and texts dedicated solely to PQ tracking. Only a brief explanation is given here to explain and raise awareness of PQ surveillance.

PQ monitoring requires the right selection of monitoring equip- ment, the method of collecting data, and so on. The recorded information needs to meet only the monitoring objectives in order for the monitoring to be successful. The objective of the monitoring may be to diagnose incompatibilities between the supply and the consumer loads. In other cases, it is used to evaluate the electrical environ- ment at a particular location for the required machinery or equipment.

Preventive and predictive monitoring may require recorded volt- ages and currents to quantify the existing level of power quality. Measurement of PQ includes both time- and frequency- domain variables. PQ monitoring may be provided by the utility, customers, or any other personnel such as energy auditors.

Table 1.2.6(a) shows some important parameters that can be determined using suitable algorithms from the voltage and current waveforms. 
Table 1.2.6(a) IEEE-519: parameters that can be determined fromacquired voltage and current data

\begin{tabular}{|c|c|c|}
\hline $\begin{array}{l}\text { ANSI } \\
\text { transformer derating } \\
\text { factor }\end{array}$ & $\begin{array}{l}\text { rharmonic } \\
\text { rms current }\end{array}$ & True power factor \\
\hline $\begin{array}{l}\text { hmetic sum } \\
\text { power factor }\end{array}$ & $\begin{array}{l}\text { rharmonic } \\
\text { rms voltage }\end{array}$ & $\begin{array}{l}\text { Unsigned } \\
\text { harmonic power }\end{array}$ \\
\hline $\begin{array}{l}\text { hmetic sum } \\
\text { displacementpower } \\
\text { factor }\end{array}$ & $\begin{array}{l}\text { Current-time } \\
\text { product }\end{array}$ & $\begin{array}{l}\text { Vector sum } \\
\text { displacement factor }\end{array}$ \\
\hline \begin{tabular}{|l} 
hmetic sum \\
volt-amperes
\end{tabular} & $\begin{array}{l}\text { Negative- } \\
\text { sequence current }\end{array}$ & $\begin{array}{l}\text { Vector sum } \\
\text { power factor }\end{array}$ \\
\hline Current crest factor & $\begin{array}{l}\text { Negative- } \\
\text { sequence voltage }\end{array}$ & $\begin{array}{l}\text { Vector sum } \\
\text { volt-amperes }\end{array}$ \\
\hline Current THD & Net current & Voltage crest factor \\
\hline $\begin{array}{l}\text { Current THD } \\
\text { (rms) }\end{array}$ & $\begin{array}{l}\text { Positive- } \\
\text { sequence current }\end{array}$ & Voltage THD \\
\hline $\begin{array}{l}\text { rent total } \\
\text { interharmonic } \\
\text { distortion (TID) }\end{array}$ & $\begin{array}{l}\text { Positive- } \\
\text { sequence voltage }\end{array}$ & Voltage THD (rms) \\
\hline Current TID (rms) & $\begin{array}{l}\text { Residual } \\
\text { current }\end{array}$ & Voltage TID \\
\hline Current imbalance & rms current & Voltage TID (rms) \\
\hline $\begin{array}{l}\text { placement } \\
\text { power factor }\end{array}$ & \begin{tabular}{|l|} 
current \\
individual \\
harmonics \\
\end{tabular} & $\begin{array}{l}\text { age telephone } \\
\text { nterference factor (TIF) }\end{array}$ \\
\hline Frequency & $\begin{array}{l}\text { rms harmonic } \\
\text { current (total) }\end{array}$ & Voltage TIF (rms) \\
\hline $\begin{array}{l}\text { frequency } \\
\text { arithmetic sum } \\
\text { volt-amperes }\end{array}$ & rms voltage & Voltage imbalance \\
\hline $\begin{array}{l}\mathrm{d} \text { frequency } \\
\text { vector sum } \\
\text { volt-amperes }\end{array}$ & $\begin{array}{l}\text { rms voltage } \\
\text { individual } \\
\text { harmonics }\end{array}$ & Watt-hours \\
\hline $\begin{array}{l}\text { Harmonic } \\
\text { power (sum) }\end{array}$ & $\begin{array}{l}\text { Total fund } \\
\text { frequency reactive } \\
\text { power }\end{array}$ & Zero-sequence current \\
\hline $\begin{array}{l}\text { IEEE } 519 \\
\text { current TDD }\end{array}$ & $\begin{array}{l}\text { nsformer } \\
\text { K-factor }\end{array}$ & Zero-sequence voltage \\
\hline
\end{tabular}




\subsection{Loads that wreak havoc on power quality 1.3.1 Introduction}

Most of the electrical loads have nonlinear behavior at the AC mains. Many fluctuating loads such as furnaces, electric hammers, and frequently switching devices exhibit highly non linear behavior as electrical loads. These loads are known as nonlinear loads.

Solid-state control of AC power using diodes, thyristors, and other semiconductor switches is widely used to feed controlled power to elec- trical loads. These AC loads consisting of solid-state converters draw non-sinusoidal currents from the AC mains and behave in a nonlinear manner.

Nonlinear loads cause low system efficiency, poor power factor (PF), mal- operation of protection systems, AC capacitors overloading and nuisance tripping. They also cause distortion in the supply voltage.

Nonlinear loads exhibit different behavior thereby causing dif- ferent power quality problems, and they are therefore often classified according to their performance. The devices used for power quality improvements of such mixed nonlinear loads are connected in shunt with the loads to supply locally all their current components other than the fundamental active power component of load current. The mixed non linear loads consist of several several current fed type and voltage type of nonlinear load.

Power quality issues are caused by nonlinearloads, especially those that use solid-state controllers. To determine the appropriate power quality control instruments, it is necessary to characterise and eval- uate their behaviour.

Part 1.3 of this paper examines the classification and analysis of single-phase and three-phase nonlinear loads, as well as their results, with a focus on power quality issues. The state of the art for these non- linear loads, their classification, interpretation, modelling, and simula- tion of results and illustrations.

\subsubsection{Nonlinear Loads: A modern take}

To supply reactive power locally and reduce the pressure of reactive power on the AC mains, AC power capacitors and synchronous con- densers were used. Voltage deviation at the neutral terminal, increased losses, and harmonic voltage at the point of normal coupling arise from these harmonics and neutral current (PCC) These voltage imbalanceand fluctuation problems also affect good linear loads like AC motors, particularly induction motors, with negative sequence currents and subsequent rotor heating and increased losses, resulting in motor der- ating.

The following are few examples of nonlinear loads: 
-Fluorescent lighting and other vapor lamps with electronic ballasts

- Switched mode power supplies

- Computers, copiers, and television sets

- Printer, scanners, and fax machines

-High-frequency welding machines

- Fans with electronic regulators

- Microwave ovens and induction heating devices

-Xerox machines and medical equipment

-Variable frequency-based HVAC (heating ventilation and air-conditioning) systems

- Battery chargers and fuel cells

-Electric traction

- Arc furnaces

- Cycloconverters

- Adjustable speed drives

- Static slip energy recovery schemes of wound rotor induction motors

-Wind and solar power generation

- Static VAR compensators (SVCs)

-HVDC transmission systems

- Magnet power supplies

- Plasma power supplies

-Static field excitation systems

Harmonic currents and the reactive power part of the current are drawn from the single-phase AC mains by nonlinear loads. This higher currents result in higher losses, a lower power factor, and interference with other users, networking networks, safety systems, and other electronic equipment. 


\subsubsection{Nonlinear Load Classification}

The use of non-solid-state or solid-state systems can be used to clas- sify nonlinear loads. The presence or absence of a power electronics converter in nonlinear load circuits is also important.. Few of the classification are explained below:

- Nonlinear Loads of Solid-State Device (SSD) Form-Many separate circuits in solid-state devices are used in electrical equip- ment to process $\mathrm{AC}$ power for various applications. They are nonlinear loads that draw non-sinusoidal current from the AC mains. Domestic and industrial machines are examples of single- phase non- linear loads. Single-phase distributed loads on all three stages, such as electrical ballast-based lighting systems, device loads in high-rise buildings, and all other singlephase loads, put a strain on the power supply.
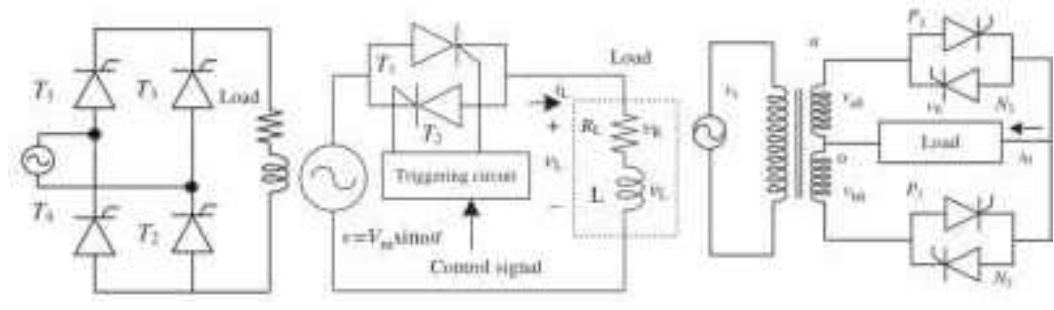

Fig1.3.3(a) Various types of non linear loads(SSD).

- Nonlinear Loads using an AC-DC Converter-The power level of AC-DC converters ranges from a few watts to a megawatt. At the AC mains, the behaviour of the filters used to filter the rec- tified DC varies depending on the type of filter used. Microwave ovens, SMPS, printers, fax machines, battery chargers, and HVDC transport devices are examples of nonlinear loads.

- Nonlinear Loads Using AC Controllers-To control the physical operation, some nonlinear loads use $\mathrm{AC}$ voltage regulators to control the $\mathrm{AC}$ rms voltage through the electrical loads. They draw harmonic currents as well as reactive power, resulting in a low power factor. They often induce unnecessary harmonic currents in single-phase spread loads on three-phase supply systems.

- Nonlinear Loads Using Cycloconverters- Cycloconverters are used in a variety of applications to transform $\mathrm{AC}$ voltage at a fixed frequency to variable voltage at a variable frequency or vice versa. Nonlinear loads include cyclocoversed large- rating synchronous motor drives in cement mills, for example.

- Nonlinear Loads using current feeding-Nonlinear loads that are stiffly current fed have a fixed pattern of harmonics which can often put a reactive power strain on the AC mains. They have a low crest factor and a smooth current waveform drawn from the AC mains. AC-DC converters feeding DC motor drives, magnet power supplies, alternator field excitation systems, operated AC-DC converters used to derive DC current source for feeding current source inverter supplying large-rating AC motor drives, HVDC transmission systems, and so on. Figure 1.3.3(b) depicts a current-fed nonlinear load of this kind. 


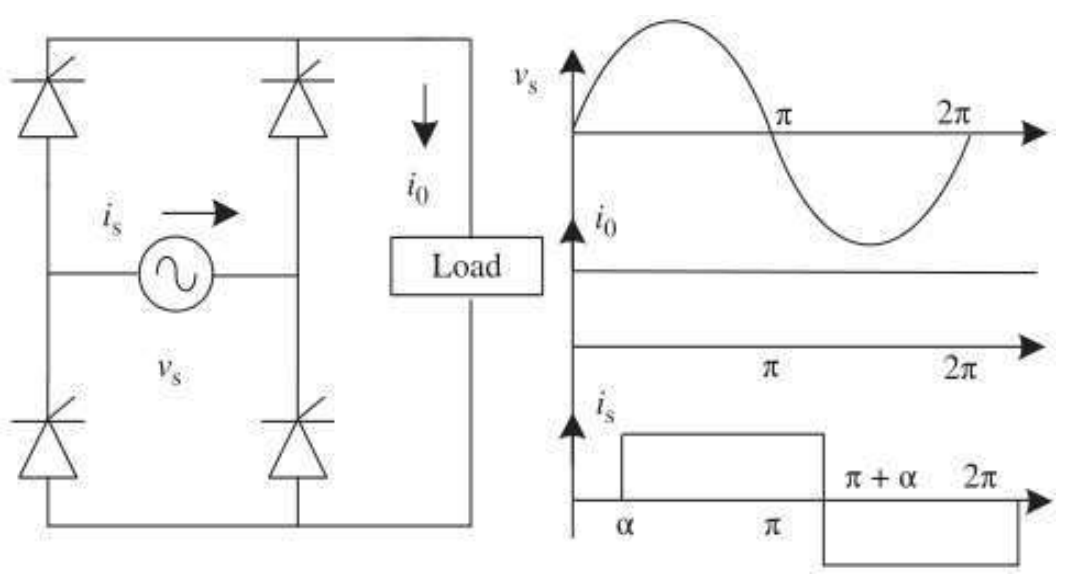

Figure 1.3.3(b) A current fed type non linear load.

- Non linear loads using voltage feeding-The rigid voltage forms of the nonlinear loads function as the drain of the harmonic currents. Typical example of this load is an AC-DC converter with a large DC capacitor on its DC bus to provide the perfect DC voltage supply for the remaining solidstate conversion operation and to draw peak current from the AC mains. Strong peak factor (as seen in Figure 1.3.3(c)). In general, they do not have a reactive power criterion, but They have a significantly larger number of harmonic currents drawn from the AC mains. Examples of loads like this include SMPS, battery chargers, front-end converters of the AC powered inverter voltage source, Electronic ballasts and other electronic equipment.
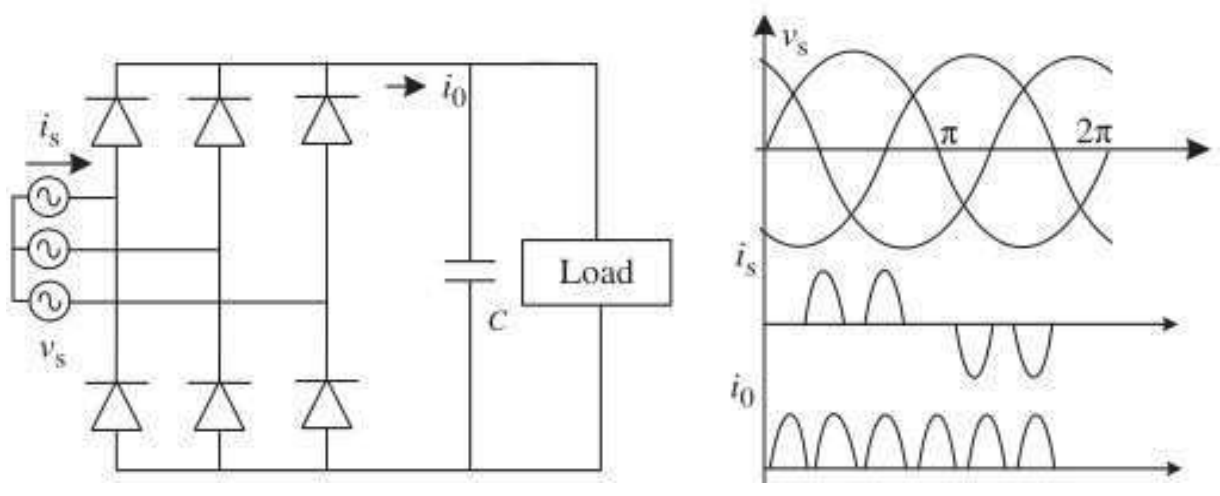

Figure1.3.3.(c) A voltage fed type non linear load.

- Mix of current Fed and Voltage Fed Nonlinear Load Types- Mixed nonlinear loads are a hybrid of current fed and voltage fed load types. This grouping includes a group of nonlinear loads and a mixture of linear and nonlinear loads. Most electrical loads consisting of solid-state converters function as nonlinear loads of this kind.

Two-Wire Non-linear Loads-A very significant number of single- phase non-linear loads are supplied by the two-wire single- phase AC mains. All of these loads, consisting of single-phase diode rectifiers, semiconverters and thyristor converters, act as non-linear loads. They pull harmonic currents and often reactive power from the AC mains as well. Typical examples of such loads are power supplies, electronic ventilator controllers, electronic ballasts, laptops, television sets, and traction. Figure 


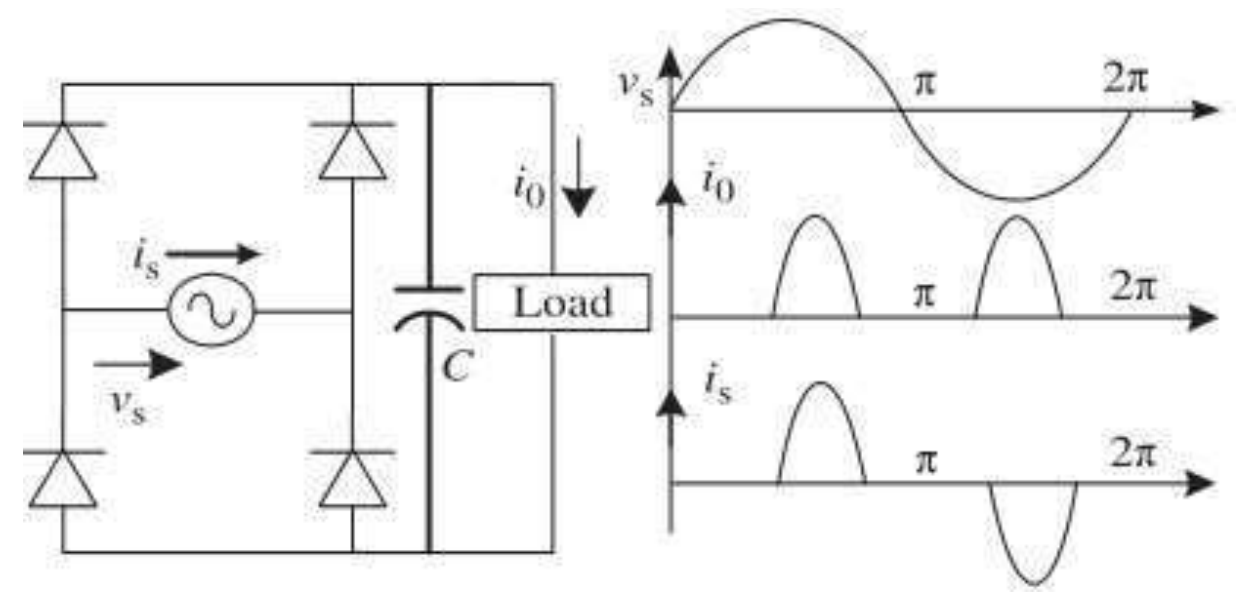

Figure 1.3.3(d) A two wire non linear load .

- Three-Wire non linear loads-Three-phase, three-wire, non-linear loads inject harmonic currents, and sometimes they pull reactive power from the AC mains, and sometimes they even have unbalanced currents. These non-linear loads are in huge numbers and absorb a large volume of electrical energy. Typical examples are ASDs using DC and AC engines, HVDC trans- mission systems, and wind power conversion. Figure 1.3.3(e) indicates the latest form of nonlinear load being fed.
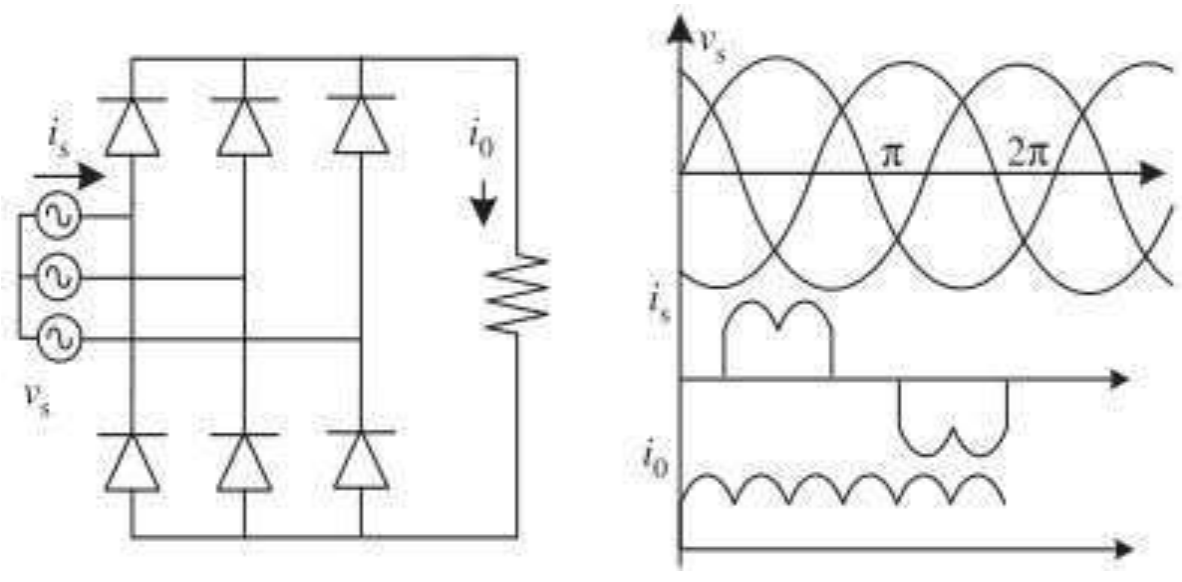

Figure 1.3.3(e) A three wire non linear load.

- Four-Wire Nonlinear Loads-A significant number of single- phase non-linear loads with a neutral conductor can be supplied from the three-phase AC mains. Apart from the harmonic cur- rents, the reactive power and the unbalanced currents, they also induce excessive neutral current due to the harmonic currents and the unbalancing of these three phase loads. Typical exam- ples are machine loads and mechanical ballast-based steam lighting systems. They often induce voltage deviation and voltage imbalance at the PCC and some potential at the neutral terminal. Figure 1.3.3(f) indicates the latest form of nonlinear load beingfed. 


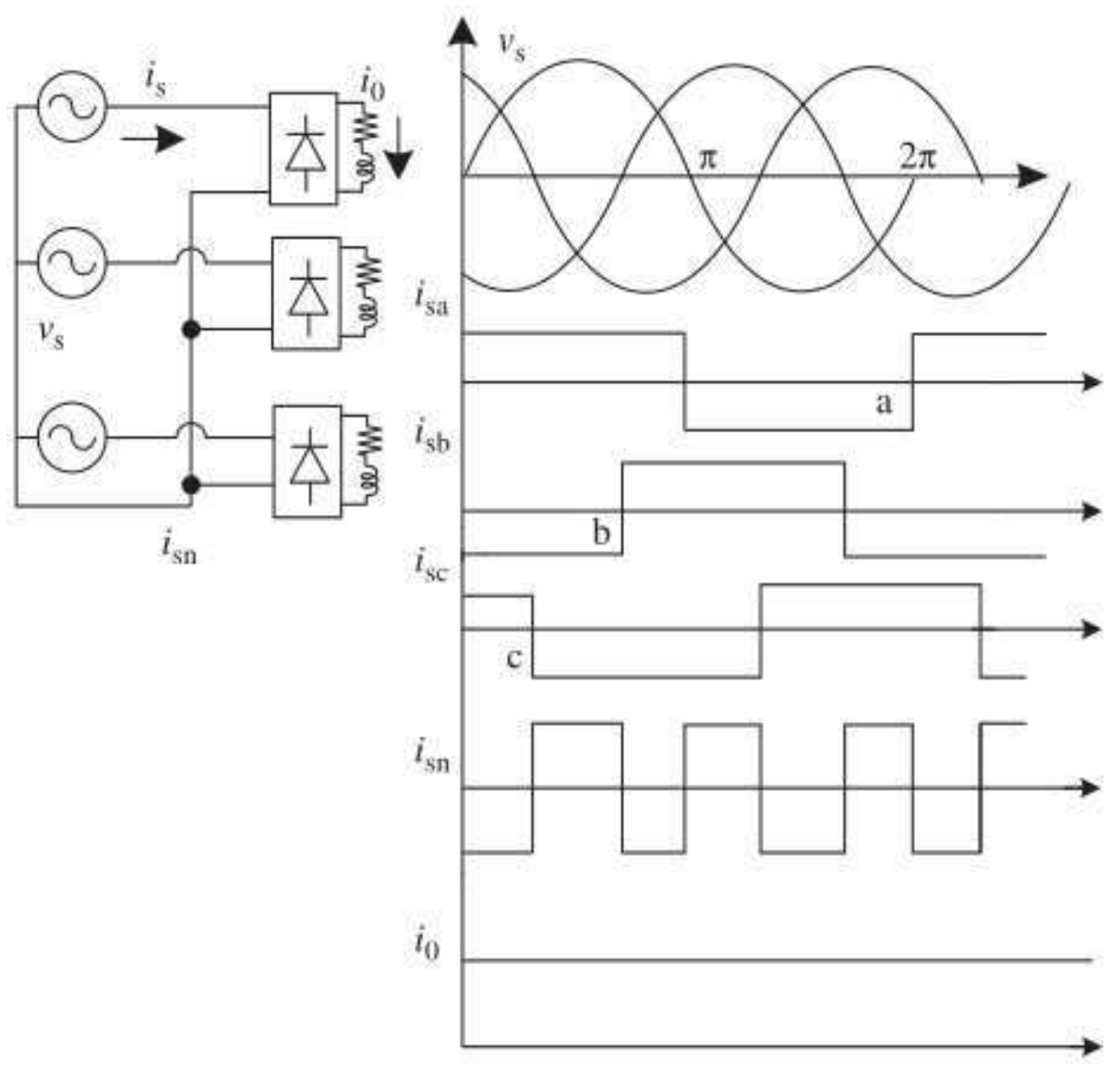

Figure 1.3.3(f) A four wire non linear load. 


\subsection{Power quality problems caused by non-linearloads}

Nonlinear loads create a host of issues with the consistency of power in the delivery system. They are injecting harmonic currents into the AC mains. These harmonic currents increase the rms value of the supply current, increase losses, causing low usage and heating of the delivery system components, and often cause distortion and notching of the voltage waveforms at the point of normal coupling due to a voltage decrease in the source impedance. Any effects are as follows:

- Increased rms value of the supply current

- Increased losses

- Poor power factor

-Poor utilization of distribution system

- Heating of components of distribution system

-Derating of the distribution system

-Distortion in voltage waveform at the point of common coupling, which indirectly affects many types of equipment

-Disturbance to the nearby consumers

-Interference in communication system

-Mal-operation of protection systems such as relays

-Interference in controllers of many other types of equipment

- Capacitor bank failure due to overload, resonance, harmonic amplification, and nuisance fuse operation

- Excessive neutral current

- Harmonic voltage at the neutral point Some of these nonlinear loads, in addition to harmonics, require reactive power and create unbalancing,which not only increases the severity of the abovementioned problems but also causes additional problems.

- Voltage regulation and voltage fluctuations

-Imbalance in three-phase voltages

-Derating of cables and feeders 


\section{Literature review}

By means of a comprehensive literature study of more than 200 jour- nals and books, the paper is published after researching papers from almost 45 years of ago. This paper contains studies and publications on virtually every related topic since the onset of power quality issues. This paper is planned in a new and different way from previous papers on the topic. It consists of unusual material for easy under- standing of the subject matter and a significant number of basic derivations are used in a simpler mathematical form to solve most of the problems of power quality in analytical form. Apart from this, the paper includes basic theory accompanied by drawings, waveforms and phasor diagrams. In addition to undergraduate and postgrad- uate students in the field of power efficiency, this paper would also prove useful to scholars, teachers and field engineers. The future spectrum of work can be everything from resolution of the above-mentioned problems to innovative guidelines for solving and implementing power quality corrective devices. 


\section{Result}

There are a host of economic and reliability problems related to the satisfactory service of electrical appliances. Research and development in energy quality reduction strategies is also becoming significant and critical in limiting the emissions of the supply chain.

A variety of organizations, such as IEC and IEEE, have issued various standards that define the acceptable limits of power efficiency. Many manufacturers with different brands, such as power quality analyzers and sensors, have created a range of tools for measuring and evaluating power quality indices.

Nonlinear loads are divided into various groups, taking into account the severity of the issues. An empirical analysis of the different performance indices of these nonlinear loads is conducted in depth with an aim of studying the degree of power quality they may inflict in the system.

\section{Conclusion}

Research and design of efforts to address energy quality is becoming increasingly important and crucial. IEC and IEEE have issued stan-dards that establish acceptable limits for energy efficiency. A number of manufacturers of various names have proposed a set of instruments for calculating power quality indices. 


\section{References}

[b1].Handbook of power quality Edited by Angelo B. Baggini. ISBN 978-0-470-06561-7 (cloth)

[b2].Power quality problems and mitigation techniques by B.Singh, A Chandra, K.A.

Haddad,ISBN 978-1-118-92205-7 (cloth)1

[b3]Power quality issues by S. Mikkili, A.K. Panda, ISBN-13: 978-1-4987-2963-5

[b4]Electrical power systems quality by Dr. S. Santoso, R.C. Dugan, M.F McGranaghan,H.W.Beaty,ISBN-13 : 978-1259005572

[b5]Techniques for improving the quality of electricity on the basis of reactive power compensation Fedotov Alexander Ivanovitch,Akhmetshin Azat Rinatovich,Vagapov Georgii Valerianovich,Chernova Natalia Vladimirovna.

[b6] Measurement of the electric power quality and related problems A. Ferrero, A. Menchetti, R. Sasdelli, European Transactions on Electrical Power(1996)

[b7] Analysis and Mitigation of Power Quality Issues in Distributed Generation Systems Using Custom Power Devices Hossain, Eklas, Tur, Mehmet Rida, Sanjeevaikumar, P., Ay, Selim, Khan, Imtiaj IEEE Access (2018).

[b8]R. C. Sermon, "An overview of power quality standards and guidelines from the end-user's point-of-view," Rural Electric Power Conference, 2005, San Antonio, TX, USA, 2005, pp. B1/1B1/5, doi: 10.1109/REPCON.2005.1436304. 


\section{Bibliography}

1. Stacy, E.J. and Strycula, E.C. (1974) Hybrid power filter employing both active and passive elements. US Patent 3,849,677.

2. Gyugyi, L. and Strycula, E. (1976) Active AC power filters. Proceedingsof the IEEE IAS Annual Meeting, pp. 529-535.

3. Harashima, F., Inaba, H., and Tsuboi, K. (1976) A closed-loop control system for the reduction of reactive power required by electronic converters. IEEE Transactions on Industrial Electronics and Control Instrumentation, 23(2), 162-166.

4. Epstein, E., Yair, A., and Alexandrovitz, A. (1979) Analysis of a reactive current source used to improve current drawn by static inverters. IEEE Transactions on Industrial Electronics and Control Instrumentation, 26(3), 172-177.

5. Uceda, J., Aldana, F., and Martinez, P. (1983) Active filters for staticpower converters. IEE Proceedings - Part B, 130(5), 347-354.

6. Rajagopalan, V., Jacob, A., Sévigny, A. et al. (1983) Harmonic currents compensationscheme for electrical distribution systems. Proceedings of the IFAC on Control in Power Electronics and Electrical Drives, Lausanne, Switzerland, pp. 683-690.

7. Drouin, P.L.A., Sévigny, A., Jacob, A., and Rajagopalan, V. (1983) Studies on line current harmonics' compensation scheme suitable for an electric distribution system. Canadian Electrical Engineering Journal, 8(4), 123-129.

8. Stacy, E.J. and Brennen, M.A. (1987) Active power conditioner system. US Patent $4,651,265$.

9. Takeda, M., Ikeda, K., and Tominaga, Y. (1987) Harmonic current compensation with active filter. Proceedings of the IEEE IAS Annual Meeting, pp. 808-815.

10. Peng, F.Z., Akagi, H., and Nabae, A. (1988) A novel harmonic power filter.

Proceedings of IEEE PESC'88, pp. 1151-1159.

11. Nakajima, A., Oku, K., Nishidai, J. et al. (1988) Development foactive filter with series resonant circuit. Proceedings of IEEE PESC'88, pp. 1168-1173.

12. Kohata, M., Shiota, T., Watanabe, Y. et al. (1988) A novel compensa- tion using static induction thyristors for reactive power and harmonics. Proceedings of the IEEE IAS Annual Meeting, pp. 843-849. 13. Moran, S. (1989) A line voltage regulator/conditioner for harmonic- sensitive load isolation. Proceedings of the IEEE IAS Annual Meeting, pp. 945-951.

14. Shimamura, T., Kurosawa, R., Hirano, M., and Uchino, H. (1989) Par- allel operation of active and passive filters for variable speed cycloconverter drive systems. Proceedings of IEEE IECON'89, pp. 186-191. 
15. Wong, C., Mohan, N., Wright, S.E., and Mortensen, K.N. (1989) Feasi- bility study of ACand DC-side active filters for HVDC converter terminals. IEEE Transactions on Power Delivery, 4(4), 2067-2075.

16. Peng, F.Z., Akagi, H., and Nabae, A. (1990) A new approach to har- monic compensation in power systems - a combined system of shunt passive and series active filters. IEEE Transactions on Industry Applications, 26(6), 983-990.

17. Moran, S. (1990) Line voltage regulator. US Patent 4,950,916.

18. Bou-rabee, M., Chang, C.S., Sutanto, D., and Tam, K.S. (1991) Passive and active harmonic filters for industrial power systems. Proceedings of IEEE TENCON'91, pp. 222-226.

19. Fujita, H. and Akagi, H. (1991) Design strategy for the combined system of shunt passive and series active filters. Proceedings of IEEE PESC'91, pp. 898-903.

20. Williams, S.M. and Hoft, R.G. (1991) Adaptive frequency domain con- trol of PWM switched power line conditioner. IEEE Transactions on Power Electronics, 6(4), 665-670.

21. Tanaka, T. and Akagi, H. (1991) A new combined system of series active and shunt passive filters aiming at harmonic compensation for large capacity thyristor converters. Proceedings of IEEE IECON'91, pp. 723-728.

22. Fujita, H. and Akagi, H. (1991) A practical approach to harmonic compensation in power systems - series connection of passive and active filters. IEEE Transactions on Industry Applications, 27(6), 1020-1025.

23. Banerjee, B.B., Pileggi, D., Atwood, D. et al. (1992) Design of an active series/passive parallel harmonic filter for ASD loads at a wastewater treatment plant. Proceedings of the IEEE PQA Conference, pp. 1- 7.

24. Bocchetti, G., Carpita, M., Giannini, G., and Tenconi, S. (1993) Line filter for high power inverter locomotive using active circuit for harmonic reduction. Proceedings of the Fifth EPE, pp. 267-271.

25. Mochinaga, Y., Hisamizu, Y., Takeda, M. et al. (1993) Static power conditioner using GTO converters for AC electric railway. Proceedings of the IEEE Power Conversion Conference, Yokohama, pp. 641-646.

26. Peng, F.Z., Akagi, H., and Nabae, A. (1993) Compensation characteris- tics of the combined system of shunt passive and series active filters. IEEE Transactions on Industry Applications, 29(1), 144-152.

27. Bhattacharya, S., Divan, D.M., and Banerjee, B.B. (1993) Control and reduction of terminal voltage total harmonic distortion (THD) in a hybrid series active and parallel passive filter system. Proceedings of IEEE PESC'93, pp. 779-786.

28. Balbo, N., Sella, D., Penzo, R. et al. (1993) Hybrid active filter for parallel harmonic compensation. Proceedings of EPE'93, pp. 133-138.

29. Le, J.N., Pereira, M., Renz, K., and Vaupel, G. (1994) Active damping of resonances in power systems. IEEE Transactions on Power Delivery, 9(2), 1001-1008. 
30. Czarnecki, L.S. (1994) Combined time-domain and frequency-domain approach to hybrid compensation in unbalanced nonsinusoidal systems.European Transactions on Electrical Power Engineering, 4(6), 477-484.

31. Aliouane, K., Saadate, S., and Davat, B. (1994) Analytical study and numerical simulation of the static and dynamic performances of combined shunt passive and series active filters. Proceedings of the Fifth International Conference on Power Electronics and Variable-Speed Drives, pp. 147-151.

32. Brennen, M.A. and Moran, S.A. (1994) Active power line conditioner with low cost surge protection and fast overload recovery. US Patent 5,287,288.

33. Schauder, C.D. and Moran, S.A. (1994) Multiple reference frame con- troller for active filters and power line conditioners. US Patent 5,309,353.

34. Brennen, M.A. (1994) Series-parallel active power line conditioner uti- lizing reducedturns-ratio transformer for enhanced peak voltage regulation capability. US Patent 5,319,534.

35. Brennen, M.A. (1994) Active power line conditioner having capability for rejection of common- mode distur- bances. US Patent 5,319,535.

36. Brennen, M.A. (1994) Active power line conditioner utilizing har- monic frequency injection for improved peak voltage regulation. US Patent 5,349,517.

37. Brennen, M.A. and Moran, S.A. (1994) Active power line conditioner with a derived load current fundamental signal for fast dynamic response. US Patent 5,351,178.

38. Brennen, M.A. and Moran, S.A. (1994) Highly fault tolerant active power line conditioner. US Patent 5,351,180.

39. Brennen, M.A., Moran, S.A., and Gyugyi, L. (1994) Low cost active power line conditioner. US Patent 5,351,181.

40. Brennen, M.A. and Moran, S.A. (1994) Active power line conditioner with synchronous transformation control. US Patent 5,355,025.

41. Brennen, M. (1994) Series-parallel active power line conditioner uti- lizing temporary link energy boosting for enhanced peak voltage regulation capability. US Patent 5,355,295.

42. Krah, J.O. and Holtz, J. (1994) Total compensation of line side switching harmonics in converter fed AC locomotives. Proceedings of the IEEE IAS Annual Meeting, pp. 913-920.

43. Rastogi, M., Mohan, N., and Edris, A.A. (1995) Hybrid-active filtering of harmonic currents in power systems. IEEE Transactions on Power Delivery, 10(4), 1994-2000.

Chang, C.S., Lock, K.S., Wang, F., and Liew, A.C. (1995) Harmonic level control schemes and evaluation methods in power system. Proceedings of the International Conference on Energy Management and Power Delivery(EMPD'95), vol. 1, pp. 146-151. 
44. Ledwich, G. and Doulai, P. (1995) Multiple converter performance and active filtering. IEEE Transactions on Power Electronics, 10(3), 273-279.

45. Kamran, F. and Habetler, T.G. (1995) Combined deadbeat control of a series-parallel converter combination used as a universal power filter. Proceedings of IEEE PESC'95, pp. 196201.

46. Raju, N.R., Venkata, S.S., Kagalwala, R.A., and Sastry, V.V. (1995) An active power quality conditioner for reactive power and harmonics com- pensation. Proceedings of IEEE PESC'95, pp. 209-214.

47. Moran, L., Werlinger, P., Dixon, J., and Wallace, R. (1995) A series active power filter which compensates current harmonics and voltage unbal- ance simultaneously. Proceedings of IEEE PESC'95, pp. 222-227.

48. Kamran, F. and Habetler, T.G. (1995) A novel on-line UPS with uni- versal filtering capabilities. Proceedings of IEEE PESC'95, pp. 500-506.

49. Lim, Y.C., Park, J.K., Jung, Y.G. et al. (1995) Developmentf a simulator for compensation performance evaluation of hybrid active power filter using three-dimensional current co-ordinate. Proceedings of the IEEE Inter- national Conference on Power Electronics and Drive Systems, pp. 427-432.

50. Moran, S.A. and Brennen, M.B. (1995) Active power line conditioner with fundamental negative sequence compensation. US Patent 5,384,696.

51. Bhattacharya, S. and Divan, D.M. (1995) Hybrid series active/par- allel passive power line conditioner with controlled harmonic injection. US Patent 5,465,203.

52. Bhattacharya, S., Divan, D.M., and Banerjee, B. (1995) Active filter solutions for utility interface. Proceedings of IEEE ISIE'95, pp. 53-63.

53. Bhattacharya, S. and Divan, D. (1995) Design and implementation of a hybrid series activefilter system. Proceedings of IEEE PESC'95, pp. 189-195.

54. Rastogi, M., Mohan, N., and Edris, A.A. (1995) Filtering of harmonic currents and damping of resonances in power systems with a hybrid-active filter. Proceedings of IEEE APEC'95, pp. 607-612.

55. Akagi, H. and Fujita, H. (1995) A new power line conditioner for harmonic compensation in power systems. IEEE Transactions on Power Delivery, 10(3), 1570-1575.

56. Lin, C.E., Su, W.F., Lu, S.L. et al. (1995) Operation strategy of hybrid harmonic filter in demand- side system. Proceedings of the IEEE IAS Annual Meeting, pp. 1862-1866.

57. Bhattacharya, S. and Divan, D. (1995) Synchronous frame based con- troller implementation for a hybrid series active filter system. Proceedings of the IEEE IAS Annual Meeting, pp. 2531-2540.

58. Dixon, J., Venegas, G., and Moran, L. (1995) A series active powefilter based on a sinusoidal current controlled voltage source inverter. Proceedings of IEEE IECON'95, pp. 639-644. 
59. Kamath, G., Mohan, N., and Albertson, D. (1995) Hardware imple- mentation of a novel reduced rating active filter for 3-phase, 4-wire loads. Proceedings of IEEE APEC'95, pp. 984-989.

60. Tolbert, L.M., Hollis, H.D., and Hale, P.S., Jr. (1996) Evaluation of har- monic suppression devices. Proceedings of the IEEE IAS Annual Meeting,

61. Rim, G.H., Kang, I., Kim, W.H., and Kim, J.S. (1996) A shunt hybrid active filter with two passive filters intandem.Proceedingso f IEEE APEC'96, pp. 361-366.

62. Bhattachaya, S. and Divan, D.M. (1996) Hybrid series active, parallel passive, power line conditioner for harmonic isolation between a supply and load. US Patent 5,513,090.

63. Mohan, N. and Rastogi, M. (1996) Hybrid filter for reducing distortionin power system. US Patent 5,548,165.

64. Zyl, A.V., Enslin, J.H.R., Steyn, W.H., and Spee, R. (1996) A new unified approach to power quality management. IEEE Transactions on Power Electronics, 11(5), 691-697.

65. Libano, F.B., Simonetti, D.S.L., and Uceda, J. (1996) Frequency char- acteristics of hybrid filter systems.

Proceedings of IEEE PESC'96, pp. 1142-1148.

66. Kurowski, T., Strzelecki, R., and Supronowicz, H. (1996) A new method of alternating current harmonic

compensation in parallel systems of hybrid filters. Proceedings of IEEE ISIE'96, vol. 2, pp. 596601.

67. Strzelecki, R., Benysek, G., and Frackowiak, L. (1996) Dynamic proper- ties of hybridfilters in regenerative braking thyristor systems. Proceedings of IEEE ISIE'96, vol. 2, pp. 612-617.

68. Yoshioka, Y., Konishi, S., Eguchi, N., and Hin o(11996) Selferm- mutated static flicker compensator for arc furnaces. Proceedings of IEEE APEC'96, pp. 891897.

69. Raju, N.R., Venkata, S.S., and Sastry, V.V. (1996) A decoupled series compensator for voltage regulation and harmonic compensation. Proceed- ings of IEEE PESC'96, pp. 527-531. 70. Akagi, H. (1996) New trendns aictivefilters for power conditioning. IEEE Transactions on Industry Applications, 32(6), 1312-1322.

71. Muthu, S. and Kim, J.M.S. (1997) Steady-state operating character- istics of unified active power filters. Proceedings of IEEE APEC'97, pp. 199-206.

72. Hafner, J., Aredes, M., and Huemann, K (997) A shunt active powfeliter applied to high voltage distribution lines. IEEE Transactions on Power Delivery, 12(1), 266-272. 
73. Mariscotti, A. (1997) Low frequency conducted disturbances compensa- tion using a hybrid filter system. Proceedings of IEEE ISIE'97, vol. 2, pp. 405-410.

74. Segura, N., Iglcsias, R.S.J., Sanchez, P.B., and Perez, J.N. (1997) Experimental performance of passive and hybrid filters applied to AC/DC converters fed by a weak AC system. Proceedings of IEEE ISIE'97, vol. 2, pp. 600-605.

75. Bhattacharya, S., Cheng, P.T., and Divan, D.M. (1997) Hybrid solutions for improving passive filter performance in high power applications. IEEE Transactions on Industry Applications, 33(3), 732-747.

76. Rujula, A.A.B., Arasanz, J.S., Badia, M.S., and Estopinan, A.L. (1997) Searching for the better topology and control strategy in hybrid power filters. Proceedings of EPE'97, pp. 4.8254.830 .

77. Libano, F., Cobos, J., and Uceda, J. (1997) Simplified control strategy for hybrid active filters. Proceedings of IEEE PESC'97, vol. 2, pp. 1102-1108.

78. Khositkasame, S. and Sangwongwanich, S. (1997) Design of harmonic current detector and stability analysis of a hybrid parallel active filter. Pro- ceedings of the IEEE Power Conversion Conference, Nagaoka, pp. 181-186.

79. Pittorino, L.A., du Toit, J.A., and Enslin, J.H.R. (1997) Evaluation of converter topologies and controllers for power quality compensators under unbalanced conditions. Proceedings of IEEE PESC'97, pp. 1127-1133.

80. Jeon, S.-J. and Cho, G.-H. (1997) A series-parallel compensated unin- terruptible power supply with sinusoidal input current and sinusoidal output voltage. Proceedings of IEEE PESC'97, pp. 297-303.

81. Maeda, T., Watanabe, T., Mechi, A. et al. (1997) A hybrid single-phase power active filter for high order harmonics compensation in converter- fed high speed trains. Proceedings of the Power Conversion Conference, Nagaoka, pp. 711-717.

82. Fujita, H. and Akagi, H. (1997) An approach to harmonic current-free AC/DC power conversion for large industrial loads: the integration of a series active filter with a double series diode rectifier. IEEE Transactions on Industry Applications, 33(5), 1233-1240.

83. Su, W.F., Lin, C.E., and Huang, C.L. (1998) Hybrid filter application for power quality improvement. Electric Power Systems Research, 47, 165-171.

84. Cheng, P.T., Bhattacharya, S., and Divan, D.M. (1998) Power line harmonic reduction by hybrid parallel active/ passive filter system with square wave inverter and DC bus control. US Patent 5,731,965.

85. Aredes, M., Heumann, K., and Watanabe, E.H. (1998) An universal active power line conditioner. IEEE Transactions on Power Delivery, 13(2), 545-551.

86. Cheng, P.T., Bhattacharya, S., and Divan, D.M. (1998) Hybrid par- allel active/passive filter system with dynamically variable inductance. US Patent 5,757,099. 
87. Cheng, P.T., Bhattacharya, S., and Diwan, D.M. (1998) Control of square-wave inverters in high- power hybrid active filter systems. IEEE Transactions on Industry Applications, 34(3), 458-472.

88. Sitaram, I.M., Padiyar, K.R., and Ramanarayanan, V. (1998) Digital simulation of a hybrid active filter - an active filter in series with shunt passive filter. Proceedings of the IEEE PES Meeting on Power Quality, pp. 65-71.

89. Jung, G.H. and Cho, G.H. (1998) New power active filter with simple low cost structure without tuned filters. Proceedings of IEEE PESC'98, pp. 217-222.

90. Basic, D., Ramsden, V.S., and Muttick, P.K. (1998) Performance of combined power filters in harmonic

compensation of high-power cycloconverter drives. Proceedings of the IEEEConference on Power Electronics and Variable Speed Drives, PublicationNo. 456, pp. 674-679.

91. Venkta, S.S., Raju, N.R., Kagalwala, R.A., and Sastry, V.V. (1998) Active power conditioner for reactive andharmonic compensation having PWM and stepped wave inverters. US Patent 5,751,138.

92. Singh, B.N., Chandra, A., Al-Haddad, K., and Singh, B. (1998) Fuzzy control algorithm for universal active filter. Proceedings of the IEEE Power Quality Conference, pp. 73-80.

93. Huang, S.J., Wu, J.C., and Jou, H.L. (1998) Electric-power-quality improvement using parallel active-power conditioners. IEE Proceedings - Generation, Transmission and Distribution, 145(5), 597-603.

94. Barbosa, P.G., Santisteban, J.A., and Watanabe, E.H. (1998)

Shunt-series active power filter for rectifiers AC and DC sides. IEE Pro- ceedings - Electric Power Applications, 145(6), 577-584.

95. Su, W.F., Lin, C.E., and Huang, C.L. (1998) Hybrid filter application for power quality improvement. Electric Power Systems Research, 47, 165-171.

96. Peng, F.Z., McKeever, J.W., and Adams, D.J. (1998) A power line conditioner using cascade multilevel inverters

for distribution systems. IEEE Transactions on Industry Applications, 34(6), 1293-1298.

97. Chen, G., Li, M., Zhongming, Y., and Zhaoming, Q. (1998) A hybrid solution to active power filter for the purpose of harmonic suppression and resonance damping. Proceedings of IEEE POWERCON'98, pp. 1542-1546.

98. Peng, F.Z. (1998) Application issues of active power filters. IEEE Industry Applications Magazine, 4(5), 21-30.

99. Peng, F.Z. and Adams, D.J. (1999) Harmonic sources and filtering approaches series/parallel, active/passive, and their combined power fil- ters. Proceedings of the IEEE IAS Annual Meeting, pp. 448- 455.

100. Koczara, W. and Dakyo, B. (1999) AC voltage hybrid filter. Proceed- ings of IEEE INTELEC'99, pp. 92. 
101. Liu, J., Yang, J., and Wang, Z. (1999) A new approach for single-phase harmonic current detecting and its application in a hybrid active power filter. Proceedings of IEEE IECON'99, pp. 849-854.

102. Huang, S.J. and Wu, J.C. (1999) Design and operation of cascaded active power filters for the reduction of harmonic distortions in power system. IEE Proceedings - Generation, Transmission and Distribution, 146(2), 193-199.

103. Tolbert, L.M.Me,Peng, F.Z. 2 and Habetler, T.G. (1999) A multilevel converter based uni power conditioner. Proceedings of IEEE PESC'99, pp. 393-399.

104. Valouch, V. and Dolejskova, S. (1999) Evaluation of performance cri- teria of hybrid power filters. Proceedings of EPE'99, p. 9.

105.Bester, D.D., le Roux, A.D., du Mouton, T.H., and Enslin, J.H.R. (1999) Evaluation of power- ratings for active power quality compensators. Proceedings of EPE'99.

106.Alexa, D. (1999) Combined filtering system consisting of passive filter with capacitors in parallel with diodes and

low-power inverter. IEE Proceedings - Electric Power Applications, 146(1), 88-94.

107.Li, R., Johns, A.R., Elkateb, M.M., and Robinson, F.V.P. (1999) Comparative study of parallel hybrid filters in resonance damping. Proceed- ings of the IEEE International Conference on Electrical Power Engineering, Power Tech Budapest'99, p. 230.

108. Yonghai, X., Xiangning, X., and Lianguang, L. (1999) New approaches of low cost hybrid active filter. Proceedings of the IEEE International Conference on Electric Power Engineering, Power Tech Budapest'99, pp. 291-295.

109.Singh, B.N., Singh, B., Chandra, A., and Al-Haddad, K. (1999) Dig- ital implementation of a new type of hybrid filter with simplified control strategy. Proceedings of IEEE APEC'99, vol. 1, pp. 642-648.

110.Al-Zamel, A.M. and Torrey, D.A. (1999) A three-phase hybrid series passive/shunt active filter system. Proceedings of IEEE APEC'99, pp. 875-881.

111.Duro, B., Ramsden, V.S., and Muttik, P. (1999) Minimization of active filter rating in high power hybrid filter systems. Proceedings of IEEE PEDS'99, July, vol. 2, pp. 1043-1048.

112.Singh, B.N., Singh, B., Chandra, A., and Al-Haddad, K. (1999) A new control scheme of series hybrid active filter. Proceedings of IEEE PESC'99, vol. 1, pp. 249-154.

113.Park, S., Sung, J.H., and Nam, K. (1999) A new parallel hybrid filter configuration minimizing active filter size. Proceedings of IEEE PESC'99, vol. 1, pp. 400-405.

114.Laren, E. and Delmerico, R. (1999) Hybrid active power filter with programmed impedance characteristics. US Patent 5,910,889.

115.Shahalami, S.H., Benchaita, L., and Saadate, S. (1999) A comparative study between two structures of hybrid active filter for harmonic compensa- tion of a 18-thyristors cycloconverter fed induction motor drive. Proceedings of EPE'99.

116.Li, R., Elkateb, M.M., Jones, A.T., and Robinson, F.V. (1999) Perfor- mance of parallel hybrid filters in damping harmonic resonance. Proceedings of EPE'99, p. 10. 
117.Ramirez, S., Visairo, N., Oliver, M. et al. (2000) Harmonic compen- sation in the AC mains by the use of current and voltage active filters controlled by a passivity-based law. Proceedings of the IEEE International Power Electronics Congress (CIEP'02), pp. 87-92.

118. Valouch, V. (2000) Compensation of harmonic voltage source by using parallel and series active filters. Proceedings of EPE-PEMC'00, Kos $<\# 30 \mathrm{C}>$ ice, pp. 4.20-4.25.

119.Fujita, H., Yamasaki, T., and Akagi, H. (2000) A hybrid active filter for damping of harmonic resonance in industrial power systems. IEEE Trans- actions on Power Electronics, 15(2), 215-222.

120.Sung, J.H., Park, S., and Nam, K. (2000) New hybrid parallel active filter configuration minimising active filter size. IEE Proceedings - Electric Power Applications, 147, 93-98.

121.Basic, D., Ramsden, V.S., and Muttick, P.K. (2000) Hybrid filter control system with adaptive filters for selective elimination of harmonics and interharmonics. IEE Proceedings Electric Power Applications, 147(3), 295-303.

122.Park, S., Han, S.B., Jung, B.M. et al. (2000) A current control scheme based on multiple synchronous reference frames for parallel hybrid active filter. Proceedings of the Third International Conference on Power Elec- tronics and Motion Control (PIEMC'00), pp. 218-223.

123. Yuwen, B., Jiang, X., and Zhu, D. (2000) Study on the performance of the combined power filter with unsymmetrical condition. Proceedings of the Third International Conference on Power Electronics and Motion Control (PIEMC'00), pp. 365-370.

124.Guozhu, C., Lu, Z., and Zhaoming, Q. (2000) The design and implement of series hybrid active power filter for variable nonlinear loads. Proceed- ings of the Third International Conference on Power Electronics and Motion Control (PIEMC'00), pp. 1041-1044.

125.Karthik, K. and Quaicoe, J.E. (2000) Voltage compensation and harmonic suppression using series active and shunt passivefilters.ProceedingsoftheIEEECanadianConferenceonElectricaland-

ComputerEngineering,pp.582-586.

126.Rivas, D., Moran, L., Dixon, J., and Espinoza, J. (2000) A simple control scheme for hybrid active power filter. Proceedings of IEEE PESC'00, pp. 991-996.

127.Basic, D., Ramsden, V.S., and Muttik, P.K. (2000) Selective compen- sation of cycloconverter harmonics and interharmonics by using a hybrid power filter system. Proceedings of IEEE PESC'00, vol. 3, pp. 1137-1142.

128.Akagi, H. (2000) Active and hybrid filters for power conditioning. Proceedings of IEEE ISIE'00, vol. 1, pp. TU26-TU36.

129.Tong, M., Feng, P., and Jiang, J. (2000) The design of a hybrid power filter based on variable structure control. Proceedings of the Third World Congress on Intelligent Control and Automation, pp. 2982-2986.

130.Senini, S. and Wolfs, P.J. (2000) Hybrid active filter for harmonically unbalanced three-phase 
Bibliograplyy

3.1

three-wire railway traction loads. IEEE Transac- tions on Power Electronics, 15(4), 702-710.

131.Cheng, P.T., Bhattacharya, S., and Divan, D.M. (2000) Operations of the dominant harmonic active filter (DHAF) under realistic utility condi- tions. Proceedings of IEEE IAS'00, pp. 2135-2142.

132.van Schoor, G., van Wyk, J.D., and Shaw, I.S. (2000) Modelling of a power network compensated by hybrid power filters with different distorted loads. Proceedings of IEEEIHQPC'00, October, pp. 301-306.

133.Alexa, D., Rosu, E., Lazar, A. et al. (2000) Analysis of operation for the combined filtering system consisting of passive filter with capacitors in parallel with diode. Proceedings of PCIM'00.

134.Zhan, C., Wong, M., Wang, Z., and Han, Y. (2000) DSP control of power conditioner for improving power quality. Proceedings of the IEEE PES Meeting, pp. 2556-2561.

135.Tolbert, L.M., Peng, F.Z., and Habetler, T.G. (2000) A multilevel con- verter-based universal power conditioner. IEEE Transactions on Industry Applications, 36(6), 596-603.

136.Singh, P., Pacas, J.M., and Bhatia, C.M. (2000) A novel 3-phase hybrid harmonic and reactive power compensator. Proceedings of EPE-PEMC'00, Kos<\#30C >ice, pp. 4.26-4.31. 137.Singh, B. and Verma, V. (2000) Modeling and control of series hybrid power filter with self supporting DC bus. Eleventh National Power System Conference, December 20-22, IISc, Bangalore, vol. 2, pp. 620-626.

138.Graovac, D., Katic<\#301〉, V., and Rufer, A. (2000) Universal power quality system an extension to universal power quality conditioner. Proceedings of EPE-PEMC'00, Kos $<\# 30$ C $>$ ice, pp. 4.32-4.38.

139.Graovac, D., Katic, V., and Rufer, A. (2000) Power quality com- pensation using universal power quality conditioning system. IEEE Power Engineering Review, 20(12), 58-60.

140.Graovac, D., Kati, V., and Rufer, A. (2000) Solving supply and load imperfections using universal power quality conditioning system. Proceed- ings of PCIM'00.

141.Moran, L., Pastorini, I., Dixon, J., and Wallace, R. (2000) Series active power filter compensates current harmonics and voltage unbalance simul- taneously. IEE Proceedings Generation, Transmission and Distribution, 147(1), 31-36.

142.da Silva, S.A.O., Donoso-Garcia, P.F., Cortizo, P.C., and Seixas, P.F. (2000) A comparative analysis of control algorithms for three-phase line- interactive UPS systems with series-parallel active power- line conditioning using SRF method. Proceedings of IEEE PESC'00, pp. 1023-1028.

143.Peng, F.Z. (2000) Power line conditioner using cascade multilevel inverters for voltage regulation, reactive power correction, and harmonic filtering. US Patent 6,075,350.

144.Sérgio, A., daSilva, O., Donso-Garcia, P. etal. (2000) Three-phase line- interactive UPSsystems with series-parallel active power line conditioning for high power quality. Proceedings of EPE-PEMC'00, Kos $<\# 30 \mathrm{C}>$ ice, pp. 3.130-3.135.

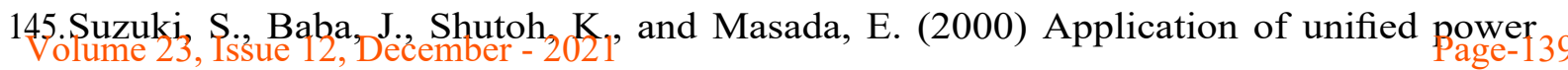


flow controller for power

quality control. Proceedings of EPE-PEMC'00, Kos<\#30C>ice, pp.4.165-4.170.

146.Prieto, J. and Salmerón, P.R. (2000) Control design of an active con- ditioner for threephase load compensation. Proceedings of PCIM'00.

147.Hojo, M., Matsui, N., and Ohnishi, T. (2000) Instantaneous line voltage controlled harmonics compensator. Proceedings of IEEE IECON'00, pp. 754-759.

148.El Shatshat, R., Kazerani, M., and Salama, M.M.A. (2001) Multi converter approach to active power filtering using current source converters. IEEE Transactions on Power Delivery, 16(1), 38-45.

149.le Roux, A.D. and Mouton, H.D.T. (2001) A series-shunt compen- sator with combined UPS operation. Proceedings of the IEEE International Symposium on Industrial Electronics (ISIE'01), pp. 2038- 2043.

150.Basu., M., Das, S.P., and Dubey, G.K. (2001) Experimental investiga- tion of performance of a single-phase UPQC for voltage sensitive and non- linear loads. Proceedings of IEEE PEDS'01, pp. 218-222.

151.Lin, B.R. and Yang, B.R. (2001) Current harmonics elimination with a series hybrid active filter. Proceedings of the IEEE International Sympo- sium (ISIE'01), pp. 566-570.

152.Zhao, C., Li, G., Chen, Z., and Li, G. (2001) Design and realization of a new hybrid power filter system used in single-phase circuit. Proceedings of IEEE IECON'01, pp. 1067-1071.

153.Chae, B.-S., Lee, W.-C., Lee, T.-K., and Hyun, D.-S. (2001) A fault protection scheme for unified power quality conditioners. Proceedings of IEEE-PEDS'01, pp. 66-71.

154.Kandil, T.A. and Quaicoe, J.E. (2001) A new approach to voltage and harmonic compensation. Proceedings of the IEEE Canadian Conference on Electrical and Computer Engineering, pp. 747-752.

155.Cao, R., Zhao, J., Shi, W. et al. (2001) Series power quality compen- sator for voltage sags, swells, harmonics and unbalance. Proceedings of the IEEE PES Conference and Exposition on Transmission and Distribution, pp. 543-547.

156.Chen, S. and Joos, G. (2001) A unified series-parallel deadbeat control technique for an active power quality conditioner with full digital imple- mentation. Proceedings of the IEEE IAS Annual Meeting, pp. 172-178.

157.Graovac, D., Rufer, A., Katic, V., and Knezevic, J. (2001) Unified power quality conditioner based on current source converter topology. Pro- ceedings of EPE'01.

158.Singh, P., Pacas, J.M., and Bhatia, C.M. (2001) A novel 3-phase hybrid harmonic and reactive power compensator. EPE Journal, 11(4), 14-19. 
159.Jou, H.-L., Wu, J.C., and Wu, K.D. (2001) Parallel operation of passive power filter and hybrid power filter for harmonic suppression. IEE Proceed- ings -Generation, Transmission and Distribution, 148(1), 8-14.

160.Al-Zamil, A.M. and Torrey, D.A. (2001) A passive series, active shunt filter for high power applications. IEEE Transactions on Power Electronics, 16(1), 101-109.

161.Guozhu, C., Zhengyu, L., and Zhaoming, Q. (2001) The special design considerations for series hybrid active power filter. Proceedings of IEEE PESC'01, pp. 560-564.

162.Chen, L. and von Jouanne, A. (2001) A comparison and assessment of hybrid filter topologies and control algorithms. Proceedings of IEEE PESC'01, vol. 2, pp. 565-570.

163.Guozhu, C., Zhengyu, L., and Zhaoming, Q. (2001) A novel hybrid active power filter with two passive channels for high power application. Proceedings of IEEE PESC'01, pp. 18891892.

164.Tnani, S., Bosche, J., Gaubert, J.P., and Champenois, G. (2001) Sliding mode control of parallel hybrid filters. Proceedings of EPE'01, p. 9.

165.Zhuo, F., Li, H., Li, H., and Wang, Z. (2001) Main circuit consists of multiplex use for active power filter. Proceedings of the International Conference on Electrical Machines and Systems (ICEMS'01), pp. 504-507.

166.Jacobs, J., Fischer, A., Detjen, D., and De Doncker, R.W. (2001) An optimized hybrid power filter and VAR compensator. Proceedings of the IEEE IAS Meeting, vol. 4, pp. 24122418.

167.Braga, R.A.M., Libano, F.B., and Lemos, F.A.B. (2001) Develop- ment environment for control strategies of hybrid active power filters using Matlab and dSpace DSP. Proceedings of the IEEE Power Tech Confer- ence, pp. 6-12.

168.Detjen, D., Jacobs, J., De Doncker, R.W., and Mall, H.G. (2001) A new hybrid filter to dampen resonances and compensate harmonic currents in industrial power systems with power factor correction equipment. IEEE Transactions on Power Electronics, 16(6), 821-827.

169.Chae, B.-S., Lee, W.-C., Hyun, D.-S., and Lee, T.-K. (2001) An over- current protection scheme for series active compensators. Proceedings of IEEE-IECON'01, pp. 1509-1514.

170.Basic, D., Ramsden, V.S., and Muttik, P.K. (2001) Harmonic filtering of high-power 12pulse rectifier loads with a selective hybrid filter system. IEEE Transactions on Industrial Electronics, 48(6), 1118- 1127.

171.Joep, J., Dirk, D., and Rik, D.D. (2001) A new hybrid filter versus a shunt active power filter. Proceedings of EPE'01, p. 11.

172.Prieto, J., Salmerón, P., and Vázquez, J.R. (2001) Control implemen- tation of a three-phase load compensation active conditioner. Proceedings of EPE'01, p. 10.

173.Alexa, D., Lazar, A., Rosu, E. et al. (2001) A new efficient filtering system having passive filters with capacitors in parallel with diodes for large rated harmonic currents. Proceedings of PCIM'01. 
174.Peng, F.Z. (2001) Harmonic sources and filtering approaches. IEEE Industry Applications Magazine, 7(4), 18-25.

175.Wang, Y., Yang, J., Wang, Z. et al. (2002) Rating analysis and design of coupling transformer for single-phase

parallel hybrid active filter. Proceedings of IEEE PESC'02, pp. 602-606.

176.Lin, B.R., Huang, C.H., and Yang, B.R. (2002) Control scheme of hybrid active filter for power quality

improvement. Proceedings of the IEEE International Conference on Indus- trial Technology (ICIT'02), pp. 317-322.

177.Lin, B.-R., Yang, B.-R., and Tsai, H.-R. (2002) Analysis and operation of hybrid active filter for harmonic elimination. Electric Power Systems Research, 62(3), 191-200.

178.Senini, S.T. and Wolfs, P.J. (2002) Systematic identification and review of hybrid active filter topologies. Proceedings of IEEE PESC'02, pp. 394-399.

179.Kim, S. and Enjeti, P. (2002) A new hybrid active power filter (APF) topology. IEEE Transactions on Power Electronics, 17(1), 48-54.

180.Morimoto, H., Ando, M., Mochinaga, Y. et al. (2002) Development of railway static power conditioner used at substation for Shinkansen. Pro- ceedings of the IEEE Power Conversion Conference, Osaka, pp. 1108-1111.

181.Rodriguez, P., Pindado, R., and Bergas, J. (2002) Alternative topology for three-phase four-wire PWM converters applied to a shunt active power filter. Proceedings of IEEE IECON'02, pp. 2939-2944.

182.Deng, Z.F., Jiang, X.J., and Zhu, D.Q. (2002) A novel hybrid filter to cancel the neutral harmonic current. Proceedings ofthe IEEE IAS Meeting, vol. 1, pp. 59-63.

183.Prieto, J., Saimeron, P., Vazquez, J.R., and Alcantara, J. (2002) A series-parallel configuration of active power filters for VAR and harmonic compensation. Proceedings of IEEE IECON'02, pp. 2945- 2950.

184.da Silva, S.A.O., Donoso-Garcia, P.F., Cortizo, P.C., and Seixas, P.F. (2002) A threephase line- interactive UPS system implementation with series-parallel active power-line conditioning capabilities. IEEE Transac- tions on Industry Applications, 38(6), 1581-1590. 185.Chiang, S.J., Ai, W.J., and Lin, F.J. (2002) Parallel operation of capacity-limited three- phase four-wire active power filters. IEE Proceedings

- Electric Power Applications, 149(5), 329-336.

186.Lin, B.R., Yang, B.R., and Hung, T.L. (2002) Implementation of a hybrid series active filter for harmonic current and voltage compensations Proceedings of the IEEE International Conference on Power Electronics, Machines and Drives, pp. 598-603.

187.Escobar, G., Stankovic, A.M., Cardenas, V., and Mattavelli, P. (2002) A controller based on resonant filters for a series active filter used to com- pensate current harmonics and voltage unbalance. Proceedings of the IEEE International Conference on Control Applications, pp. 712.

188.Sadek, K. and Pereira, M. (2002) Hybrid filter for an alternating current network. US Patent $6,385,063 \mathrm{~B} 1$. 
189.Rechka, S., Ngandui, T., Jianhong, X., and Sicard, P. (2002) A com- parative study of harmonic detection algorithms for active filters and hybrid active filters. Proceedings of IEEE PESC'02, pp. 357-363.

190.Guozhu, C., Zhengyu, L., Zhaoming, Q., and Peng, F.Z. (2002) A new serial hybrid active power filter using

controllable current source. Proceedings of IEEE PESC'02, pp. 364-368.

191.Rivas, D., Moran, L., Dixon, J., and Espinoza, J. (2002) A simple control scheme for hybrid active power filter. IEE Proceedings - Generation, Transmission and Distribution, 149(4), 485-490.

192.Darwish, M.K., El-Habrouk, M., and Kasikci, I. (2002) EMC compliant harmonic and reactive power compensation using passive filter cascaded with shunt active filter. EPE Journal, 12(3), 43-50.

193.Senini, S. and Wolfs, P.J. (2002) Analysis and design of a multiple-loop control system for a hybrid active filter. IEEE Transactions on Industrial Electronics, 49(6), 1283-1292.

194.Sun, Z., Jiang, X., and Zhu, D. (2002) Study of novel traction substation hybrid power quality compensator. Proceedings of IEEE POWERCON'02, pp. 480-484.

195.Lin, B.R., Yang, B.R., and Tsai, H.R. (2002) Analysis and operation of hybrid active filter for harmonic

elimination. Electric Power Systems Research, 62, 191-200.

196.Jacobs, J., Detjen, D., and De Doncker, R. (2002) A new hybrid filter versus a shunt active power filter.

Proceedings of EPE'02, Aachen.

197.Rahmani, S., Al-Haddad, K., and Fnaiech, F. (2002) A series hybrid power filter to compensate harmonic currents

and voltages. Proceedings of IEEE IECON'02, pp. 644-649.

198.Rahmani, S., Al-Haddad, K., and Fnaiech, F. (2002) A new PWM control technique applied to three-phase shunt

hybrid power filter. Proceedings of IEEE IECON'02, pp. 727-732.

199.Rahmani, S., Al-Haddad, K., and Fnaiech, F. (2002) A hybrid struc- ture of series active and passive filters to achieving power quality criteria. Proceedings of the IEEE International Conference on Systems, Man and Cybernetics, pp. 1-6.

200.Singh, B.N. (2002) Implementation of a hybrid filter with a potential application to adjustable speed compressor

drives for air quality control. Journal of Electric Power Components \&Systems (EPCS), 30(11), 10911126.

201.Rivas, D., Moran, L., Dixon, J., and Espinoza, J. (2003) Improving pas- sive filter compensation performance with active techniques. IEEE Transac- tions on Industrial Electronics, 50(1), 161-170. 
202.Ba, A.O. and Barry, A.O. (2003) Active filter analysis by the harmonic impedance compensation method. Part II. Proceedings of the IEEE Cana- dian Conference on Electrical and Computer Engineering.

203.Mendalek, N., Al-Haddad, K., Dessaint, L.-A., and Casoria, S. (2003) A new regulation algorithm applied to a hybrid power filter. Proceedings of the IEEE Canadian Conference on Electrical and Computer Engineering.

204.Srianthumrong, S. and Akagi, H. (2003) A medium-voltage trans- formerless AC/DC power conversion system consisting of a diode rectifier and a shunt hybrid filter. IEEE Transactions on Industry Applications, 39(3),

874-882.

205.van Schoor, G., van Wyk, J.D., and Shaw, I.S. (2003) Training and optimization of an artificial neural network controlling a hybrid power filter. IEEE Transactions on Industrial Electronics, 50(3), 546- 553.

206.Barrero, F., Martinez, S., Yeves, F. et al. (2003) Universal and recon- figurable to UPS active power filter for line conditioning. IEEE Transactions on Power Delivery, 18(1), 283-290. 207.Chiang, S.J. (2003) A three-phase four-wire power conditioner with load-dependent voltage regulation for energy saving. Proceedings of IEEE APEC'03, pp. 159-164.

208.Jintakosonwit, P., Fujita, H., Akagi, H., and Ogasawara, S. (2003) Implementation and performance of cooperative control of shunt active fil- ters for harmonic damping throughout a power distribution system. IEEE Transactions on Industry Applications, 39(2), 556-564.

209.Monteiro, L.F.C., Aredes, M., and Moor Neto, J.A. (2003) A con- trol strategy for unified power quality conditioner. Proceedings of IEEE ISIE'003.

210.Sannino, A., Stevenson, J., and Larsson, T. (2003) Power-electronic solutions to power quality problems. Electric Power Systems Research, 66, 71-82.

Bakhshai, A.R., Karimi, H., and Saeedifard, M. (2003) A new adaptive harmonic extraction scheme for single- phase active power filters. Proceed- ings of IEEE International Symposium on Circuits and Systems SCAS'03), pp. 268-271.

211.Singh, B. and Verma, V. (2003) Control of hybrid filter with self- supporting DC bus. Journal of the Institution of Engineers (India), 83, 307-312.

212.Srianthumrong, S. and Akagi, H. (2003) A medium-voltage trans- formerless AC/DC power conversion system consisting of a diode rectifier and a shunt hybrid filter. IEEE Transactions on Industry Applications, 39(3), 874-882.

213.Akagi, H., Srianthumrong, S., and Tamai, Y. (2003) Comparisons in circuit configuration and filtering performance between hybrid and pure shunt active filters. Proceedings of the IEEE IAS Annual Meeting, pp. 1195-1202.

214.Singh, B. and Verma, V. (2004) Hybrid of tandem connected series active and series passive filters for varying rectifier loads. Proceedings of the 13th National Power Systems Conference (NPSC'04), December 27-30, IIT Madras, vol. II, pp. 929-935. 
215.Singh, B., Verma, V., Chandra, A., and Al-Haddad, K. (2005) Hybrid filters for power quality improvement. IEE Proceedings - Generation, Trans- mission and Distribution, 152(3), 365-378.

216.Singh, B., Verma, V., and Garg, V. (2005) Passive hybrid filter for varying rectifier loads. Proceedings of the IEEE Conference on Power Electronics and Drive Systems (PEDS'05), November 28- December 1, Kualalumpur, Malaysia, vol. 2, pp. 1306-1311.

217.Akagi, H. (2005) Active harmonic filters. Proceedings of the IEEE, 93(12), 2128-2141.

218.Singh, B. and Verma, V. (2006) An indirect current control of hybrid power filter for varying loads. IEEE Transactions on Power Delivery, 21(1), 178-183.

219.Singh, B. and Verma, V. (2006) Indirect current control of series hybrid filter: an experimental study. Proceedings of the IEEE International Sym- posium on Industrial Electronics (ISIE-2006), July 9-12, Montréal, Québec, Canada, pp. 1364-1369.

220.Singh, B. and Verma, V. (2007) An improved hybrid filter for com- pensation of current and voltage harmonics for varying rectifier loads. Inter- national Journal of Electrical Power \& Energy Systems, 29(4), 312-321.

221.Verma, V. and Singh, B. (2009) Design and implementation of a cur- rent controlled parallel hybrid power filter. IEEE Transactions on Industry Applications, 45(5), 1910-1917.

222.Nastran, J., Cajhen, R., Seliger, M., and Jereb, P. (1994) Active power filter for non-linear AC loads. IEEETransactions on Power Electronics, 9(1), 92-96.

223.Caciotta M., Leccese F., Trifiro A., From Power Quality to Perceived Power Quality, National Congress.

224.EN ISO 9000, Quality management systems - Fundamentals and vocab- ulary, 2005.

225.Handbook of power quality / Edited by Angelo B. Baggini. ISBN 978- 0-470-06561-7 (cloth) 226.Power quality problems and mitigation techniques by B.Singh, A Chandra, K.A. Haddad, ISBN 978-1-118-92205-7 (cloth)

227.Techniques for improving the quality of electricity on the basis of reac- tive power compensation Fedotov Alexander Ivanovitch,Akhmetshin Azat Rinatovich,Vagapov Georgii Valerianovich,Chernova Natalia Vladimirovna

228.Power quality issues by S. Mikkili, A.K. Panda, ISBN-13: 978-1-4987- 2963-5[?]Electrical power systems quality by Dr. S. Santoso, R.C. Dugan,

M.F McGranaghan,H.W.Beaty,ISBN-13 : 978-1259005572.

229. Measurement of the electric power quality and related problems A. Fer- rero, A. Menchetti, R. Sasdelli European Transactions on Electrical Power, (1996)

230.Analysis and Mitigation of Power Quality Issues in Distributed Gener- ation Systems Using Custom Power Devices Hossain, Eklas, Tur, Mehmet Rida, Sanjeevaikumar, P., Ay, Selim, Khan, Imtiaj. IEEE Access(2018)

231.R. C. Sermon, "An overview of power quality standards and guidelines from the enduser's point-of-view," Rural Electric Power Conference, 2005, San Antonio, TX, USA, 2005, pp. B1/1-B1/5, doi: 10.1109/REPCON.2005.1436304. 